\title{
Changing climate both increases and decreases European river floods
}

Günter Blöschl1,37*, Julia Hall ${ }^{1,37}$, Alberto Viglione ${ }^{1,2}$, Rui A. P. Perdigão1 , Juraj Parajka1 , Bruno Merz ${ }^{3}$, David Lun ${ }^{1}$, Berit Arheimer ${ }^{4}$, Giuseppe T. Aronica ${ }^{5}$, Ardian Bilibashi ${ }^{6}$, Miloň Boháč ${ }^{7}$, Ognjen Bonacci ${ }^{8}$, Marco Borga $^{9}$, Ivan Čanjevac $^{10}$, Attilio Castellarin ${ }^{11}$, Giovanni B. Chirico ${ }^{12}$, Pierluigi Claps ${ }^{2}$, Natalia Frolova ${ }^{13}$, Daniele Ganora ${ }^{2}$, Liudmyla Gorbachova ${ }^{14}$, Ali Gül ${ }^{15}$, Jamie Hannaford ${ }^{16}$, Shaun Harrigan ${ }^{17}$, Maria Kireeva ${ }^{13}$, Andrea Kiss ${ }^{1}$, Thomas R. Kjeldsen ${ }^{18}$, Silvia Kohnová19 ${ }^{\text {, Jarkko J. Koskela }}{ }^{20}$, Ondrej Ledvinka ${ }^{7}$, Neil Macdonald ${ }^{21,22}$, Maria Mavrova-Guirguinova ${ }^{23}$, Luis Mediero ${ }^{24}$, Ralf Merz ${ }^{25}$, Peter Molnar ${ }^{26}$, Alberto Montanari ${ }^{11}$, Conor Murphy ${ }^{27}$, Marzena Osuch ${ }^{28}$, Valeryia Ovcharuk ${ }^{29}$, Ivan Radevski ${ }^{30}$, José L. Salinas ${ }^{1}$, Eric Sauquet ${ }^{31}$, Mojca Šraj ${ }^{32}$, Jan Szolgay ${ }^{19}$, Elena Volpi ${ }^{33}$, Donna Wilson ${ }^{34}$, Klodian Zaimi ${ }^{35}$ \& Nenad Živkovićc ${ }^{36}$

Climate change has led to concerns about increasing river floods resulting from the greater water-holding capacity of a warmer atmosphere ${ }^{1}$. These concerns are reinforced by evidence of increasing economic losses associated with flooding in many parts of the world, including Europe ${ }^{2}$. Any changes in river floods would have lasting implications for the design of flood protection measures and flood risk zoning. However, existing studies have been unable to identify a consistent continental-scale climatic-change signal in flood discharge observations in Europe ${ }^{3}$, because of the limited spatial coverage and number of hydrometric stations. Here we demonstrate clear regional patterns of both increases and decreases in observed river flood discharges in the past five decades in Europe, which are manifestations of a changing climate. Our results-arising from the most complete database of European flooding so farsuggest that: increasing autumn and winter rainfall has resulted in increasing floods in northwestern Europe; decreasing precipitation and increasing evaporation have led to decreasing floods in medium and large catchments in southern Europe; and decreasing snow cover and snowmelt, resulting from warmer temperatures, have led to decreasing floods in eastern Europe. Regional flood discharge trends in Europe range from an increase of about 11 per cent per decade to a decrease of 23 per cent. Notwithstanding the spatial and temporal heterogeneity of the observational record, the flood changes identified here are broadly consistent with climate model projections for the next century ${ }^{4,5}$, suggesting that climatedriven changes are already happening and supporting calls for the consideration of climate change in flood risk management.

River floods are among the most costly natural hazards. Global annual average losses are estimated at US $\$ 104$ billion $^{6}$ and are expected to increase with economic growth, urbanization and climatic change $\mathrm{e}^{2,7}$. Physical arguments of increased heavy precipitation resulting from the enhanced water-holding capacity of a warmer atmosphere and the occurrence of numerous large floods have exacerbated concerns of increasing flood magnitudes ${ }^{1}$. However, observations of individual extreme events do not necessarily imply that the long-term statistical trends of flood discharge are also increasing ${ }^{3}$.

In Europe, a climatic-change signal in flood discharges over the past five decades has been demonstrated in relation to changes in the timing of floods within the year ${ }^{8}$. For example, in northeastern Europe, warmer air temperatures have led to earlier spring snowmelt floods. However, changes in flood discharges are still contested because no coherent large-scale observational evidence has been available so far at the continental scale, owing to the limited spatial coverage and number of hydrometric stations ${ }^{3}$. Several studies point towards increases in flood discharges in western Europe in the past five decades. Their findings include upward trends in flood discharges in $15 \%$ of stations ${ }^{9}$, a $44 \%$ increase in the occurrence of extreme flood discharges ${ }^{10}$ and substantial increases in the occurrence of major floods in medium-sized catchments ${ }^{11}$. However, these studies are not fully representative of Europe because the stations are mainly clustered around western Europe.

Here we analyse the most comprehensive dataset of flood observations in Europe ${ }^{12}$ and show that the changing climate has increased river flood discharges in some regions of Europe but decreased floods in others. We base our analysis on river discharge observations from 3,738 gauging stations for the period 1960-2010. The catchment areas range between $5 \mathrm{~km}^{2}$ and $100,000 \mathrm{~km}^{2}$. For each station, we extracted a series of measurements consisting of the highest peak discharge recorded in each calendar year, the annual maximum peak flow. We estimated the trend in each series using the Theil-Sen slope estimator, tested the statistical significance with the Mann-Kendall test and estimated regional trends by spatial interpolation. We also derived the long-term evolution of floods using a ten-year moving-average filter. Finally, we analysed in a similar fashion the change signal of three plausible drivers

\footnotetext{
${ }^{1}$ Institute of Hydraulic Engineering and Water Resources Management, Technische Universität Wien, Vienna, Austria. ${ }^{2}$ Department of Environment, Land and Infrastructure Engineering (DIATI), Politecnico di Torino, Turin, Italy. ${ }^{3} \mathrm{Helmholtz}$ Centre Potsdam, GFZ German Research Centre for Geosciences, Potsdam, Germany. ${ }^{4}$ Swedish Meteorological and Hydrological Institute, Norrköping, Sweden. ${ }^{5}$ Department of Engineering, University of Messina, Messina, Italy. ${ }^{6} \mathrm{CSE}-$ Control Systems Engineer, Renewable Energy Systems \& Technology, Tirana, Albania. ${ }^{7}$ Czech Hydrometeorological Institute, Prague, Czechia. ${ }^{8}$ Faculty of Civil Engineering, Architecture and Geodesy, Split University, Split, Croatia. ${ }^{9}$ Department of Land, Environment, Agriculture and Forestry, University of Padova, Padua, Italy. ${ }^{10}$ Department of Geography, Faculty of Science, University of Zagreb, Zagreb, Croatia. ${ }^{11}$ Department of Civil, Chemical, Environmental and Materials Engineering (DICAM), Università di Bologna, Bologna, Italy. ${ }^{12}$ Department of Agricultural Sciences, University of Naples Federico II, Naples, Italy. ${ }^{13}$ Department of Land Hydrology, Lomonosov Moscow State University, Moscow, Russia. ${ }^{14}$ Department of Hydrological Research, Ukrainian Hydrometeorological Institute, Kiev, Ukraine. ${ }^{15}$ Department of Civil Engineering, Dokuz Eylul University, Izmir, Turkey.

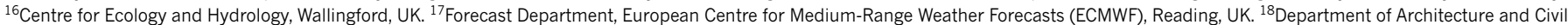
Engineering, University of Bath, Bath, UK. ${ }^{19}$ Department of Land and Water Resources Management, Faculty of Civil Engineering, Slovak University of Technology in Bratislava, Bratislava, Slovakia. ${ }^{20}$ Finnish Environment Institute, Helsinki, Finland. ${ }^{21}$ Department of Geography and Planning, University of Liverpool, Liverpool, UK. ${ }^{22}$ Institute of Risk and Uncertainty, University of Liverpool, Liverpool, UK. ${ }^{23}$ University of Architecture, Civil Engineering and Geodesy, Sofia, Bulgaria. ${ }^{24}$ Department of Civil Engineering: Hydraulic, Energy and Environment, Universidad Politécnica de Madrid, Madrid, Spain. ${ }^{25}$ Department for Catchment Hydrology, Helmholtz Centre for Environmental Research (UfZ), Halle, Germany. ${ }^{26}$ Institute of Environmental Engineering, ETH Zurich, Zurich, Switzerland. ${ }^{27}$ Irish Climate Analysis and Research Units (ICARUS), Department of Geography, Maynooth University, Maynooth, Ireland. ${ }^{28}$ Department of Hydrology and Hydrodynamics, Institute of Geophysics Polish Academy of Sciences, Warsaw, Poland. ${ }^{29}$ Hydrometeorological Institute, Odessa State Environmental University, Odessa, Ukraine. ${ }^{30}$ Institute of Geography, Faculty of Natural Sciences and Mathematics, Ss. Cyril and Methodius University, Skopje, North Macedonia. ${ }^{31}$ Irstea, UR RiverLy, Lyon-Villeurbanne, France. ${ }^{32}$ Faculty of Civil and Geodetic Engineering, University of Ljubljana, Ljubljana, Slovenia. ${ }^{33}$ Department of Engineering, University Roma Tre, Rome, Italy. ${ }^{34}$ Norwegian Water Resources and Energy Directorate, Oslo, Norway. ${ }^{35}$ Institute of Geo-Sciences, Energy, Water and Environment (IGEWE), Polytechnic University of Tirana, Tirana, Albania. ${ }^{36}$ Faculty of Geography, University of Belgrade, Belgrade, Serbia. ${ }^{37}$ These authors contributed equally: 


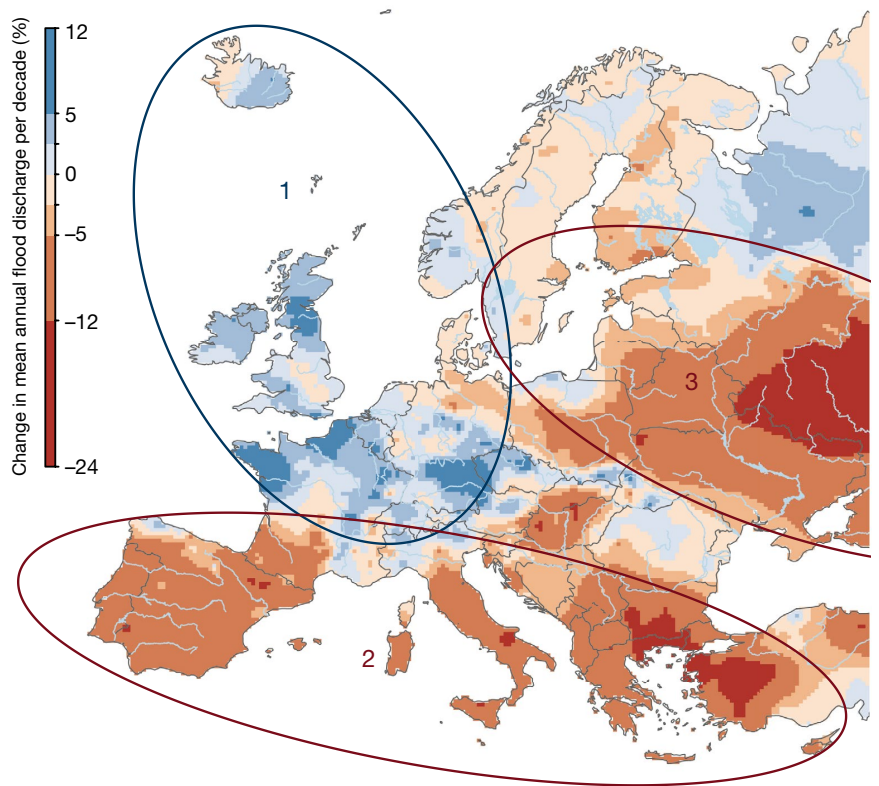

Fig. 1 | Observed regional trends of river flood discharges in Europe (1960-2010). Blue indicates increasing flood discharges and red denotes decreasing flood discharges (in per cent change of the mean annual flood discharge per decade). Numbers 1-3 indicate regions with distinct drivers. 1, Northwestern Europe: increasing rainfall and soil moisture. 2, Southern Europe: decreasing rainfall and increasing evaporation. 3, Eastern Europe: decreasing and earlier snowmelt. The trends are based on data from $n=2,370$ hydrometric stations. For uncertainties see Extended Data Fig. 2b.

of floods: the annual maximum seven-day precipitation, the highest monthly soil moisture in each year, and the spring (January to April) mean air temperature as a proxy for snowmelt and snowfall-to-rain transition. We examined the consistency between changes in these drivers and changes in floods by comparing their change patterns and using Spearman rank correlation coefficients.

Our data show a clear regional pattern in flood trends across Europe (Fig. 1). Relative to the mean flood discharges over 1960-2010, regional trends range from an increase of $+11.4 \%$ to a decrease of $-23.1 \%$ per decade (Fig. 1). The uncertainties on the regional trends (Extended Data Fig. 2 b) are small (typically between $1 \%$ and $2 \%$ per decade) relative to the spatial signal. Local trends (Extended Data Fig. 2a) at stations range from an increase of $+17.8 \%$ to a decrease of $-28.8 \%$ in the long-term station mean per decade. The spatial patterns of trends are grouped into three main regions. In northwestern Europe (Fig. 1, region 1), about $69 \%$ of stations show an increasing flood trend (Extended Data Table 2a) with an average local increase of $+2.3 \%$ per decade. In southern Europe (Fig. 1, region 2), around 74\% of stations show a decreasing trend, with a regional average trend of $-5 \%$ per decade. In eastern Europe (Fig. 1, region 3), about 78\% of stations show a decreasing flood trend with an average decrease of $-6 \%$ per decade. In northern Scandinavia and northwestern Russia, trends are less pronounced.

To interpret these changes we focused on seven hotspots of change, for which flood trends are particularly clear and flood processes are broadly similar ${ }^{8}$ (Extended Data Fig. 2). Because floods result from the interaction between precipitation, soil moisture and snowmelt ${ }^{13}$, we analysed the temporal evolution of these drivers, using air temperature as a surrogate for snowmelt, and compared it to that of floods (Extended Data Fig. 4a-g). Depending on the region, some of these drivers can be more important than others in explaining flood changes ${ }^{8}$.

In the northern United Kingdom, floods predominantly result from winter rains associated with high soil moisture ${ }^{14}$ (Extended Data Fig. 4a). The increase in flood discharges therefore closely follows increases in winter rainfall and, to some degree, those in soil moisture
(Fig. 2a). This is also shown by the statistically significant positive correlations between the temporal variability of flood discharges and these two drivers (Spearman rank correlation coefficients of $r=0.70$ and 0.36, respectively; Table 1). In western France (Fig. 2b), southern Germany and western Czechia (Fig. 2c), increases in floods are also associated with increases in rainfall, although the correlation with soil moisture is stronger than in the United Kingdom, reflecting the important role of soil moisture in flood generation during spring and summer ${ }^{15}$ (Extended Data Fig. $4 \mathrm{a}-\mathrm{c}$ ). In northern Iberia (Fig. 2d), decreasing floods are mainly caused by decreasing winter rainfall, amplified by decreasing soil moisture linked to increasing evapotranspiration ${ }^{16}$. Similarly, in the central Balkans (Fig. 2e), floods have decreased over most of the study period as a result of decreasing precipitation and soil moisture, but the trend appears to have reversed in the 1990s. In southern Finland (Fig. 2f) and western Russia (Fig. 2g), floods usually occur in the spring ${ }^{17}$, and snowmelt has an important role. The data show that air temperature has strongly increased (more than $0.5^{\circ} \mathrm{C}$ per decade) and spring and early summer flood discharges have decreased ( $r=-0.34$ and -0.55 , respectively; Table 1$)$, reflecting shallower snow packs, earlier spring thaw (Extended Data Fig. 4f-g) and decreasing snowmelt.

In northwestern Europe (Fig. 1, region 1), increases in extreme precipitation (Fig. 2a-c, Extended Data Fig. 5b) are related to the poleward shifts of the subpolar jet and of the associated storm tracks observed since the 1970s, which have been associated with more prevalent positive phases of the North Atlantic Oscillation and polar warming ${ }^{18}$. The relationship of the variability of the North Atlantic Oscillation with polar warming is still debated. Floods in the northern UK hotspot are closely aligned with increasing precipitation, resulting in a mean flood discharge trend of $+6.6 \%$ (Extended Data Table $2 c$ ).

In southern Europe (Fig. 1, region 2), the northward shift of the subtropical jet and of the associated storm tracks ${ }^{19}$, which resulted from the expansion of the Hadley cell $^{20}$, has led to decreasing precipitation, which - together with increasing evapotranspiration ${ }^{16}$ related to warmer temperatures-has reduced soil moisture substantially, by around 5\% per decade (Extended Data Figs. 5b, 6b, 7b). The combined effect has resulted in decreasing flood discharges in the catchments analysed here. Small catchments of a few square kilometres are not included in the dataset (the median catchment size of region 2 is about $400 \mathrm{~km}^{2}$ ), because they are usually not monitored or the flood series are too short for trend analyses. In small catchments, local shortduration convective storms with high intensities are more relevant for flood generation than long-duration synoptic storms, which produce floods in medium and large catchments contained in the data ${ }^{21}$. Local convective storms are expected to increase in a warmer climate ${ }^{22}$, which means that floods in small catchments may have actually increased. Additionally, soil compaction, abandoned terraces and land-cover changes may increase flood discharges in small catchments ${ }^{23}$. The difference in catchment size may explain the apparent inconsistency between the occurrence of numerous floods in small catchments in southern Europe in recent years ${ }^{21}$ and the decreasing trend in Fig. 1.

In all regions except southern Europe, increases in extreme precipitation (Fig. 2a-c, f, g, Extended Data Fig. 5b) are related to increased atmospheric blocking associated with decreasing pressure differences between Greenland and the Baltic, which has decreased the speed of zonal (west-east) flow and increased the chance of standing planetary waves ${ }^{24}$. However, only in northwestern Europe (Fig. 1, region 1 ) is the increase in extreme precipitation reflected in increased flood discharges, because winter storms in that region cause winter floods ${ }^{8}$. Farther East, snowmelt is more relevant for flood generation.

In eastern Europe, spring air temperature has increased by as much as $1^{\circ} \mathrm{C}$ per decade (Extended Data Fig. 6b). This has resulted in much less extensive spring snow cover ${ }^{25}$, a shift of snowfall to rainfall when air temperatures are around zero, shallower snow packs, earlier snowmelt ${ }^{8}$, likely increased infiltration resulting from shallower freezing depths, and therefore smaller floods, even though extreme precipitation in summer has increased ${ }^{26}$. The mean flood trend in the western Russian 

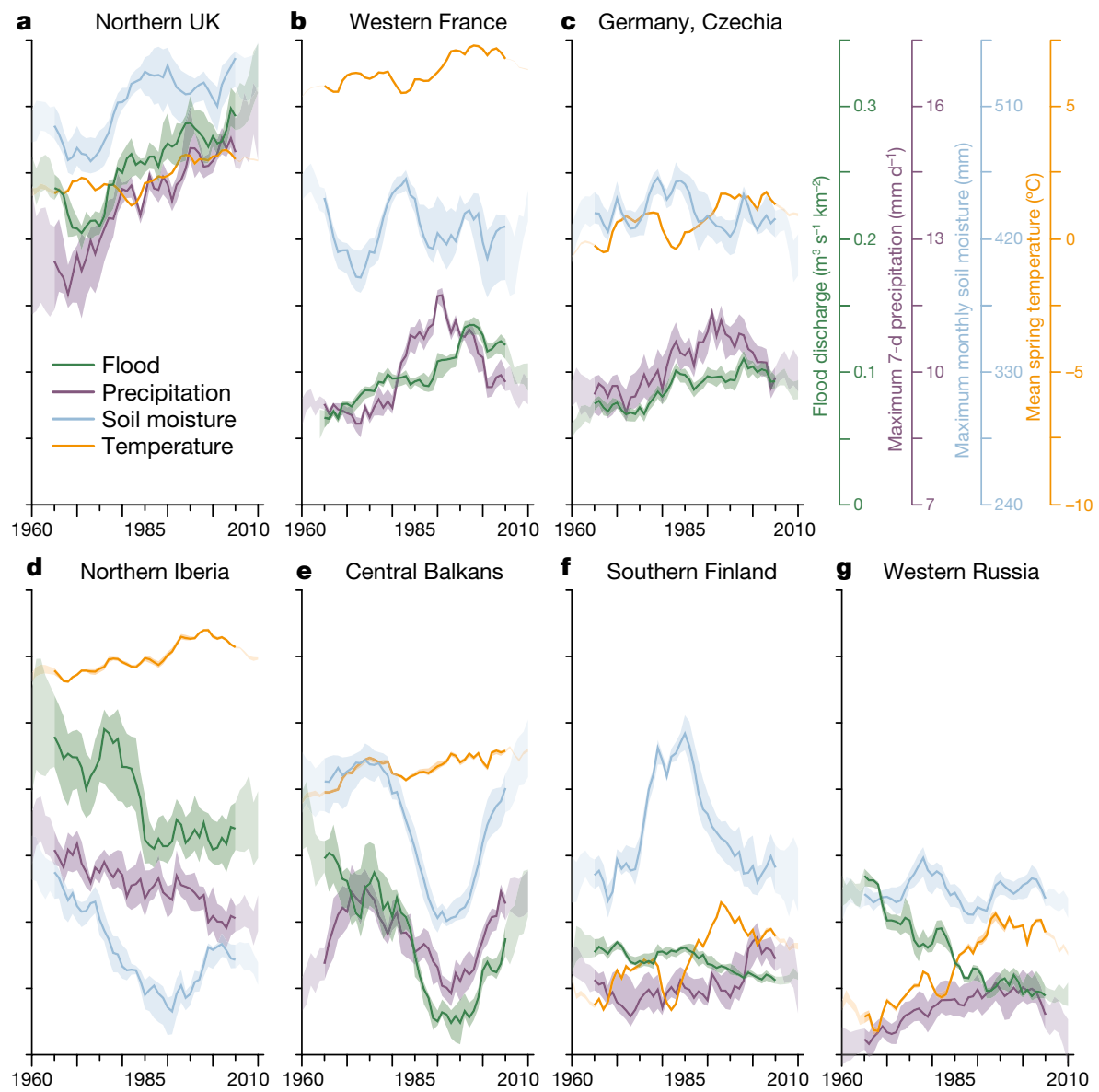

Fig. 2 Long-term temporal evolution of flood discharges and their drivers for seven hotspots in Europe. a, Northern United Kingdom; b, western France; c, southern Germany and western Czechia; d, northern Iberia; e, central Balkans; f, southern Finland; g, western Russia. The data represent observed floods (green), maximum seven-day precipitation

(purple), maximum monthly soil moisture (blue) and mean spring air temperature (orange). Solid lines show the median and shaded bands indicate the spatial variability within the hotspots (25th and 75th percentiles). All data were subjected to a ten-year moving-average filter. Vertical axes are indicated in the top right corner.

hotspot is $-18.2 \%$ (Extended Data Table 2c). Given the colder background temperature (Extended Data Fig. 6a) and larger snowpack in northwestern Russia, the increasing temperatures are not yet changing snowmelt patterns and hence not decreasing floods (Fig. 1).

Whereas previous studies have focused on a few catchments or were clustered around western Europe $e^{9-11,27}$, this study provides a continental perspective, which enables an analysis of climate processes that manifest themselves at larger scales. Isolated local or national scale studies, however, are broadly consistent with our findings.

Our results have implications for flood risk management in mediumand large-sized catchments. The trends shown in Fig. 1 are estimates of changes in the mean annual flood discharge. Because mean annual floods and more extreme floods are usually closely correlated ${ }^{28}$, similar trends could also be expected for the 100-year flood discharge, which is often the key design criterion in flood risk management. In northwest Europe (Fig. 1, region 1), flood discharges per unit catchment area (specific flood discharges) are generally high (Fig. 3). For example, on the west coast of the British and Irish isles and Norway,

the specific 100-year flood discharge during the period 1960-2010 was about $0.9 \mathrm{~m}^{3} \mathrm{~s}^{-1} \mathrm{~km}^{-2}$ (Fig. 3), with floods increasing by around $5 \%$ per decade. However, in eastern Europe (Fig. 1, region 3), specific flood discharges are rather small (Fig. 3) and are likely to become smaller in a changing climate. For example, in the Baltic countries, southern Poland and the Ukraine, the 100-year flood discharge of about $0.1 \mathrm{~m}^{3} \mathrm{~s}^{-1} \mathrm{~km}^{-2}$ would decrease to around $0.075 \mathrm{~m}^{3} \mathrm{~s}^{-1} \mathrm{~km}^{-2}$ if the observed decrease of about $5 \%$ per decade persists over the next 50 years. In southern Europe, even if flood discharges decrease in medium and large catchments, discharges are still generally high (Fig. 3 ) because of the proximity to the Mediterranean Sea and the associated heavy precipitation events ${ }^{29}$. Floods in small catchments may actually increase as a result of enhanced convective storms $\mathrm{s}^{30}$ and land-use change ${ }^{23}$.

Increasing flood discharges imply that the 100 -year flood discharge of 5 decades ago now has a return period shorter than 100 years; that is, that discharge is likely to be exceeded more often than once in 100 years on average. In northwestern Europe, what was the 100-year flood discharge in 1960 has now typically become a 50- to 80-year flood

Table 1 | Spearman's rank correlation coefficient $(r)$ between hotspot medians of the annual series of flood discharge and their drivers

\begin{tabular}{llllllll}
\hline & Northern UK & Western France & Germany, Czechia & Northern Iberia & Central Balkans & Southern Finland & Western Russia \\
\hline Precipitation & $\mathbf{0 . 7 0 * *}$ & $0.41^{*}$ & $0.40 *$ & $\mathbf{0 . 5 4 * *}$ & 0.22 & 0.08 & -0.13 \\
Soil moisture & $0.36 *$ & $\mathbf{0 . 5 7 * *}$ & $\mathbf{0 . 5 6 * *}$ & $0.37 *$ & $\mathbf{0 . 6 8 * *}$ & 0.20 & 0.30 \\
Spring temperature & $0.09^{\mathrm{a}}$ & $0.50 * *$ a & 0.04 & 0.02 & -0.29 & $-\mathbf{0 . 3 4}$ & $-\mathbf{0 . 5 5 * *}$ \\
\hline
\end{tabular}

Confidence bounds of $r$ are given in Extended Data Table 2b. Bold print indicates largest correlation coefficients in each hotspot.

$* P<0.01 ; * * P<0.001$.

aLittle snow influence on floods. 


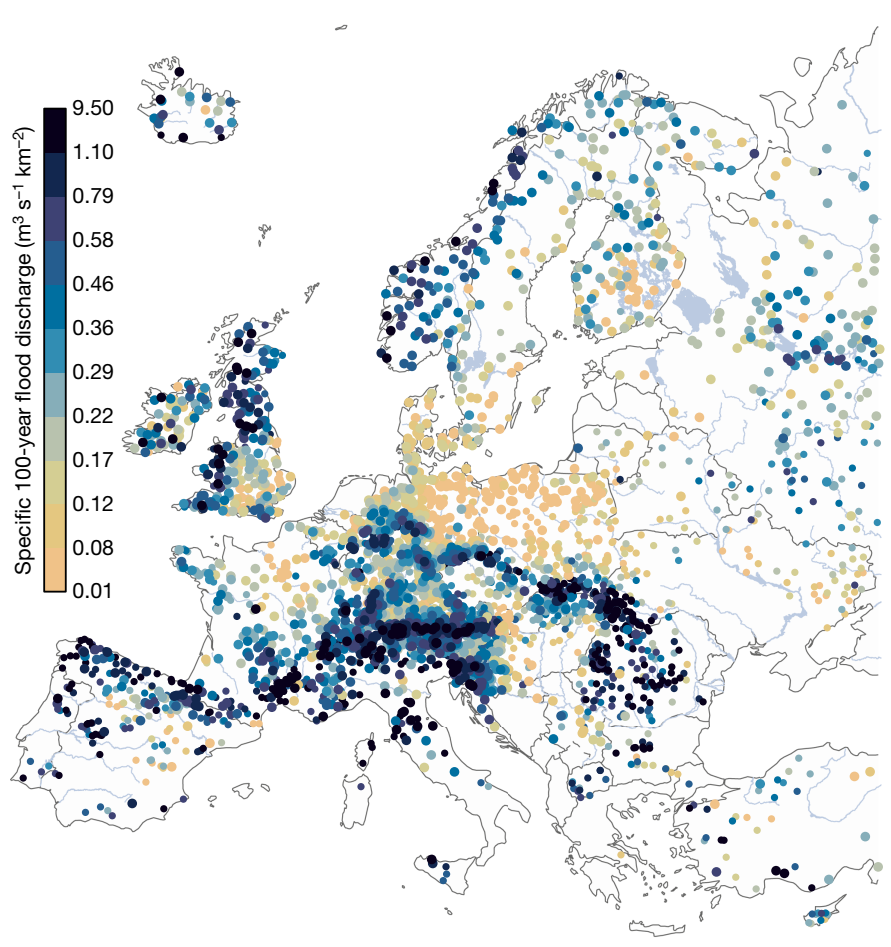

Fig. 3 Specific 100-year flood discharge in Europe. Larger points indicate $90 \%$ confidence intervals smaller than $60 \%$ of the estimate.

discharge (Extended Data Fig. 8), potentially reducing the levels of protection offered by existing flood defence structures. In eastern Europe, the 100-year flood discharge has now become a 125- to 250-year flood discharge, which will make structures less economical. Although Fig. 3 and Extended Data Fig. 8 provide a continental overview, they do not replace national-scale and local studies, for which more detailed information may be available.

It should be noted that the flood trends observed here do not necessarily extrapolate into the future, as they may be related to climate variability rather than persistent changes in time ${ }^{11}$. Also, because the trends depend on the observation period ${ }^{3}$, they may differ if the observation period is extended. However, the regions with a distinct climatic-change signal in observed flood discharges identified here are broadly coherent with the projected flood changes in Europe. Most projections for the end of the twenty-first century suggest increasing floods in (north)western Europe due to increasing precipitation, and decreasing floods in eastern and northern Europe due to increasing temperatures ${ }^{4,5}$. Hence, changes in flood discharge magnitudes are already underway, which adds credence to such projections and supports the need to account for climate-induced changes in flood risk management.

\section{Online content}

Any methods, additional references, Nature Research reporting summaries, source data, extended data, supplementary information, acknowledgements, peer review information; details of author contributions and competing interests; and statements of data and code availability are available at https://doi.org/10.1038/ s41586-019-1495-6.

Received: 30 November 2018; Accepted: 13 June 2019; Published online 28 August 2019.
1. IPCC. Managing the Risks of Extreme Events and Disasters to Advance Climate Change Adaptation (eds Field, C. B. et al.) (Cambridge Univ. Press, 2012).

2. European Academies' Science Advisory Council. Extreme Weather Events in Europe. Report No. 22 https://easac.eu/publications/details/extreme-weatherevents-in-europe/ (EASAC, 2018)

3. Hall, J. et al. Understanding flood regime changes in Europe: a state of the art assessment. Hydrol. Earth Syst. Sci. 18, 2735-2772 (2014).

4. Kundzewicz, Z. et al. Differences in flood hazard projections in Europe - their causes and consequences for decision making. Hydrol. Sci. J. 62, 1-14 (2017).

5. Thober, S. et al. Multi-model ensemble projections of European river floods and high flows at 1.5, 2, and 3 degrees global warming. Environ. Res. Lett. 13, 014003 (2018).

6. Desai, B., Maskrey, A., Peduzzi, P., De Bono, A., \& Herold, C. Making Development Sustainable: The Future of Disaster Risk Management. Global Assessment Report on Disaster Risk Reduction http://archive-ouverte.unige.ch/unige:78299 (UNISDR, 2015)

7. Winsemius, H. C. et al. Global drivers of future river flood risk. Nat. Clim. Change 6, 381-385 (2016).

8. Blöschl, G. et al. Changing climate shifts timing of European floods. Science 357, 588-590 (2017).

9. Mangini, W. et al. Detection of trends in magnitude and frequency of flood peaks across Europe. Hydrol. Sci. J. 63, 493-512 (2018).

10. Berghuijs, W., Aalbers, E., Larsen, J., Trancoso, R. \& Woods, R. Recent changes in extreme floods across multiple continents. Environ. Res. Lett. 12, 114035 (2017).

11. Hodgkins, G. A. et al. Climate-driven variability in the occurrence of major floods across North America and Europe. J. Hydrol. 552, 704-717 (2017).

12. Hall, J. et al. A European Flood Database: facilitating comprehensive flood research beyond administrative boundaries. Proc. Int. Assoc. Hydrol. Sci. 370 , 89-95 (2015)

13. Sivapalan, M., Blöschl, G., Merz, R. \& Gutknecht, D. Linking flood frequency to long-term water balance: incorporating effects of seasonality. Wat. Resour. Res. 41, W06012 (2005).

14. Bayliss, A. C. \& Jones, R. C. Peaks-over-threshold Flood Database: Summary Statistics and Seasonality. Report No. 121 (Institute of Hydrology, 1993).

15. Schröter, K., Kunz, M., Elmer, F., Mühr, B. \& Merz, B. What made the June 2013 flood in Germany an exceptional event? A hydro-meteorological evaluation. Hydrol. Earth Syst. Sci. 19, 309-327 (2015).

16. Mediero, L., Santillán, D., Garrote, L. \& Granados, A. Detection and attribution of trends in magnitude, frequency and timing of floods in Spain. J. Hydrol. 517, 1072-1088 (2014).

17. Hall, J. \& Blöschl, G. Spatial patterns and characteristics of flood seasonality in Europe. Hydrol. Earth Syst. Sci. 22, 3883-3901 (2018).

18. IPCC. Climate Change 2013: The Physical Science Basis (eds Stocker, T. F. et al.) (Cambridge Univ. Press, 2013).

19. Archer, C. L. \& Caldeira, K. Historical trends in the jet streams. Geophys. Res. Lett. $35,08803(2008)$

20. Kang, S. M. \& Lu, J. Expansion of the Hadley cell under global warming: winter versus summer. J. Clim. 25, 8387-8393 (2012).

21. Amponsah, W. et al. Integrated high-resolution dataset of high-intensity European and Mediterranean flash floods. Earth Syst. Sci. Data 10, 1783-1794 (2018).

22. Ban, N., Schmidli, J. \& Schär, C. Heavy precipitation in a changing climate: does short-term summer precipitation increase faster? Geophys. Res. Lett. 42, 1165-1172 (2015).

23. Rogger, M. et al. Land use change impacts on floods at the catchment scale: challenges and opportunities for future research. Wat. Resour. Res. 53, 5209-5219 (2017).

24. Perdigão, R. A. P., Pires, C. A. L. \& Hall, J. Synergistic dynamic theory of complex coevolutionary systems: disentangling nonlinear spatiotemporal controls on precipitation. Preprint at https://arxiv.org/abs/1611.03403 (2016).

25. Estilow, T. W., Young, A. H. \& Robinson, D. A. A long-term Northern Hemisphere snow cover extent data record for climate studies and monitoring. Earth Syst. Sci. Data 7, 137-142 (2015).

26. Frolova, N. L. et al. Hydrological hazards in Russia: origin, classification, changes and risk assessment. Nat. Hazards 88, 103-131 (2017).

27. Mediero, L. et al. Identification of coherent flood regions across Europe by using the longest streamflow records. J. Hydrol. (Amst.) 528, 341-360 (2015).

28. Salinas, J. L., Castellarin, A., Kohnova, S. \& Kjeldsen, T. Regional parent flood frequency distributions in Europe-Part 2: climate and scale controls. Hydrol. Earth Syst. Sci. 18, 4391-4401 (2014).

29. Xoplaki, E., Gonzalez-Rouco, J. F., Luterbacher, J. \& Wanner, H. Wet season Mediterranean precipitation variability: influence of large-scale dynamics and trends. Clim. Dyn. 23, 63-78 (2004).

30. Brooks, H. E. Severe thunderstorms and climate change. Atmos. Res. 123 129-138 (2013).

Publisher's note: Springer Nature remains neutral with regard to jurisdictional claims in published maps and institutional affiliations.

() The Author(s), under exclusive licence to Springer Nature Limited 2019 


\section{METHODS}

Datasets. The hydrological data used in this study were obtained from a newly created European Flood Database ${ }^{12}$, with subsequent updates, containing data from 3,738 hydrometric gauging stations from 68 European data sources for the period 1960-2010 (Extended Data Table 1). Choice of the study period was guided by a trade-off between data availability in terms of record length and spatial coverage. The database consists of the highest discharge (daily mean or instantaneous discharge) in each calendar year for each station. For consistency, we chose to analyse the annual maximum flood rather than multiple floods within a year in all stations, as in many areas only annual maxima were available. The stations are located within the domain bounded by $22.25^{\circ} \mathrm{W}-60.25^{\circ} \mathrm{E}$ and $34.25^{\circ} \mathrm{N}-71.25^{\circ} \mathrm{N}$ (Extended Data Fig. 1), and catchment areas range between $5 \mathrm{~km}^{2}$ and $100,000 \mathrm{~km}^{2}$.

The dataset was screened for data errors, and catchments that were known, or were identified, to have experienced strong human modifications (such as reservoirs) that could affect changes in flood discharges were excluded. The screening involved data pre-selection and additional visual examination of the flood records in question, analysis of flood seasonality (jumps in timing and large differences to surrounding stations) and examination of the catchment area in Google Maps. Although local human effects on the floods of individual stations cannot be excluded, the focus of this study was on regionally consistent patterns of change, for which such effects are not relevant. In a few catchments, the available flood data had been corrected for the effects of reservoirs to represent near-natural flood discharge. In a few cases, local reservoirs may influence the data, but this does not affect the regional pattern. The station density is rather uneven (Extended Data Fig. 1b). In southern Europe it is lower, as some stations were removed because of reservoir effects. In Italy, reduced record lengths are related to organizational changes of the hydrographic services ${ }^{12}$. In eastern Europe the density of available stations is generally lower than in other countries and, again, some stations were removed because of reservoir effects.

For estimating the flood discharge trends (Figs. 1, 2, Extended Data Figs. 2, 8), only stations that satisfied the following three criteria were considered: (1) at least 40 years of data were available during 1960-2010, (2) the record started in 1968 or earlier and (3) the record ended in 2002 or later. In the countries with the highest station densities (Austria, Germany and Switzerland), only stations with at least 49 years of data were included in order to obtain a more even spatial distribution across Europe. In Cyprus, Italy and Turkey, stations with at least 30 years of data were included, and in Spain stations with 40 years of data without restrictions to the start and end of the record. This selection resulted in a set of 2,370 stations with a median catchment size of $381 \mathrm{~km}^{2}$. Sensitivity analyses indicated that the large-scale spatial pattern of increasing and decreasing flood trends across Europe is not influenced by the choice of record length, although the trend of individual stations tends to be sensitive to record length-when increasing the required record length by five years, the percentage of significantly positive and negative trends (Extended Data Table 2a) changes only slightly, from $11.52 \%$ and $16.50 \%$ to $11.04 \%$ and $16.95 \%$, respectively. In this study we evaluated linear trends of the flood discharges. Alternative models of change (for example, step changes) could also be tested but are beyond the scope of this study.

For each hydrometric gauging station, the contributing catchment boundary was derived from the CCM (catchment characterization and modelling) River and Catchment Database ${ }^{31}$. Daily gridded precipitation sum and mean air temperature data from the E-OBS dataset (version 17.0) ${ }^{32}$ for the period 1960-2010 were used. The data consist of interpolated ground-based observations with a spatial resolution of $0.25^{\circ}$. Monthly gridded soil moisture data from the Climate Prediction Center (CPC) soil moisture dataset ${ }^{33}$ for the period $1960-2010$ were analysed. The data are model-calculated monthly averaged soil moisture water height equivalents with a spatial resolution of $0.5^{\circ}$.

Analysis method. As a first step, we estimated the discharge trend using the TheilSen slope estimator ${ }^{34,35}$. The trend estimator $\beta$ is the median slope calculated, using the differences of discharge $Q$ over all possible pairs of years $(i$ and $j, i<j)$ within the time series

$$
\beta=\operatorname{median}\left(\frac{Q_{j}-Q_{i}}{j-i}\right)
$$

where $\beta$ has units of cubic metres per second per year and is plotted as the percentage of the mean flood discharge per decade in Extended Data Fig. 2. The trends were tested for significance using the Mann-Kendall test ${ }^{36}$ (Extended Data Table 2a). Some false positives-that is, trends detected where no trend was present-would be expected because of the large number of stations. The MannKendall test requires the flood discharges to be temporally independent. We therefore tested whether lag-1 autocorrelation exists in the residuals from the trends. $92 \%$ of the stations did not exhibit significant lag- 1 autocorrelation at the $5 \%$ level, suggesting that the Mann-Kendall test is applicable. To identify regional spatial patterns within Europe, $\beta$ was spatially interpolated using the autoKrige function (automatic kriging) of the R automap package ${ }^{37}$. The trend patterns derived are plotted in Fig. 1 and in the background of Extended Data Fig. 2a. The uncertainty of the estimated trends at the stations was calculated by bootstrapping ${ }^{38}$ and is shown as points in Extended Data Fig. 2b. The uncertainty of the regional trends was estimated as the block-kriging standard deviation (kriging error) using the autoKrige function and is shown in the background of Extended Data Fig. 2b. The variogram estimated by the function is

$$
\gamma(d)=c_{0}+c_{1}\left[1-\frac{1}{2^{v-1} \Gamma(v)}\left(\frac{d}{c_{2}}\right)^{v} K_{v}\left(\frac{d}{c_{2}}\right)\right]
$$

where $d$ is the lag, $c_{0}=10.061\left[\%(10 \mathrm{yr})^{-1}\right]^{2}, c_{1}=57.708\left[\%(10 \mathrm{yr})^{-1}\right]^{2}$, $c_{2}=2,394.4 \mathrm{~km}, v=0.2$ and $K_{\mathrm{v}}$ is the modified Bessel function of the second kind. We used block-kriging instead of ordinary kriging because we are interested in the uncertainty of the regional estimate rather than that of the local estimate. The uncertainty was evaluated in a $200 \times 200 \mathrm{~km}^{2}$ block size, which is the scale at which we suggest Fig. 1 and Extended Data Fig. 2 a to be read.

To evaluate the robustness of the spatial trend patterns, we repeated the interpolation using only stations with significant trends (Extended Data Fig. 3a). The overall pattern is similar to that of the interpolation obtained when using all stations (Extended Data Fig. 2a). Additionally, we repeated the interpolation using only randomly selected stations with distances larger than $50 \mathrm{~km}$ from each other to examine the effect of spatial correlations on the trends (Extended Data Fig. 3b). Again, the patterns are similar.

As a second step, we selected rectangular areas or hotspots of change on the basis of similarity of discharge trends and average flood timing as a proxy for flood processes (Extended Data Fig. 2, Extended Data Table 2c). We standardized the flood series of individual stations to zero mean and unit variance to make flood changes within hotspots comparable

$$
Q_{i, k}^{0}=\frac{Q_{i, k}-\mu_{Q_{k}}}{\sigma_{Q_{k}}}
$$

where $\mu_{Q_{k}}$ and $\sigma_{Q_{k}}$ are the mean and the standard deviation of the flood discharge for station $k$, respectively. To compare results between the hotspots, we denormalized the flood series of each hotspot $h$ by the mean specific flood discharge $\mu_{h}\left(\right.$ in $\left.\mathrm{m}^{3} \mathrm{~s}^{-1} \mathrm{~km}^{-2}\right)$ over all years, and the square root $\sigma_{h}$ of the mean temporal variance:

$$
Q_{i, k}^{*}=\sigma_{h} Q_{i, k}^{0}+\mu_{h}
$$

and estimated the long-term evolution of flood discharge with a centred ten-year moving-averaging window. We plot the median of these series within each hotspot (solid lines) and the 25th and 75th percentiles of all stations in that hotspot (shaded bands) in Fig. 2. Additionally, the original local flood discharges were tested for the significance of the general trend in each hotspot using the regional Mann-Kendall test $^{39}$ (Extended Data Table 2c). Names of hotspots are only indicative and do not correspond to any exactly defined geographical area.

To investigate rain-induced effects on flood changes, we identified for each grid point of the E-OBS dataset the seven-day period with maximum precipitation in each calendar year (with at least 30 years of annual data available). Increases in spring temperatures around or below the freezing point were considered as a proxy for snow accumulation, melt and the transition from snowfall to rainfall. To understand the effect of these snowmelt processes on flood discharge, we calculated the mean air temperature from January to April. When soil moisture is high, even small rainstorms may produce floods. To understand the effect of high soil moisture on floods, we identified for each grid point of the CPC soil moisture dataset the highest monthly soil moisture in each calendar year. We repeated the trend analyses for the annual maximum precipitation, spring temperature and annual maximum monthly soil moisture (Extended Data Figs. $5-7$ ) on a $0.5^{\circ}$ grid.

In the hotspot analyses, the time series for these three climate variables were extracted on the basis of their location within the catchment boundaries (or within a buffer distance for small areas), from which the Spearman's rank correlation coefficients $(r)$ with the spatial medians of the original flood discharge series were calculated (Table 1). Confidence bounds at the 90\% confidence level of $r$ were estimated by stochastic block bootstrapping (boot package of R; random block size geometrically distributed with a mean of five years) and are given in Extended Data Table $2 \mathrm{~b}$. The long-term evolution of the three climate variables was calculated in a similar fashion as for the floods and is plotted in Fig. 2.

We also analysed changes in the timing of the climate indices and floods as proxies for changing flood processes using previously established methods ${ }^{8}$ (Extended Data Fig. 4). The timing was used to interpret the process drivers of flood discharge changes. For Extended Data Fig. 4a, b, d the snow melt index is not shown, as it is of little relevance for flooding ${ }^{8}$. 
To evaluate the relevance of the observed flood changes for flood management, the 100-year flood discharge $\left(Q_{100}\right)$ was estimated for each station using a generalized extreme value distribution

$$
Q_{T}=\xi+\frac{\eta}{\kappa}\left\{1-\left[-\ln \left(1-\frac{1}{T}\right)\right]^{\kappa}\right\}
$$

where $Q_{T}$ is the $T$-year flood discharge. The parameters $\xi, \eta$ and $\kappa$ were estimated from the flood discharge series using Bayesian inference through a Markov chain Monte Carlo (MCMC) algorithm ${ }^{40}$. Non-informative uniform prior distributions were used for $\xi$ and $\log [\eta]$, whereas a normal distribution consistent with the geophysical prior ${ }^{41}$ was used for $\kappa$. We drew 4,000 parameter samples from the posterior distributions, from which 4,000 100-year floods were calculated for each station using equation (5). The median and the relative width of the $90 \%$ credible intervals are shown in Fig. 3. For comparability of the 100-year flood discharge in catchments of different sizes, flood discharges per unit catchment area (specific flood discharges; $q_{100}=Q_{100} / A$, where $A$ is the catchment area) are shown.

If flood discharges change over time, the return period $T$ may also change; for example, the 100-year flood discharge may become the 10-year flood discharge if the flood discharges increase. Change in the return period was therefore estimated by allowing the parameter $\xi$ in equation (5) to change with time $t$ as

$$
\xi=a+b t
$$

where the posterior distributions of $a, b, \eta$ and $\kappa$ were estimated from the flood discharge series using Bayesian inference through the same MCMC algorithm ${ }^{40}$ and with non-informative uniform prior distributions for $a$ and $b$. More complex models than (6) were excluded because for most of the stations they did not outperform (6) on the basis of the Watanabe-Akaike information criterion ${ }^{42}$. We drew 4,000 parameter samples from the posterior distributions, from which 4,000 100-year flood discharges in 1960 were calculated for each station using equations (5) and (6) with $t=1,960$. The changed return period of these 4,000 flood peaks in 2010 were computed by inverting equation (5) and using equation (6) with $t=2,010$. Finally, the median of the 4,000 return periods was used as the 2010 return period of the 100-year flood discharge in 1960. Those stations for which the 5th and the 95th percentiles of the uncertainty distribution agreed in the sign of change are plotted as large points in Extended Data Fig. 8 whereas the remaining stations are plotted as smaller points to indicate the uncertainty involved in the estimation.

To identify large-scale spatial patterns, the logarithms of the 2010 return periods of the 100-year flood discharge in 1960 were spatially interpolated using the autoKrige function ${ }^{37}$ (Extended Data Fig. 8). To estimate the stationary 100-year specific flood discharge $q_{100}$ (equation (5), Fig. 3), less stringent selection criteria (at least 30 years of data) than in all the other analyses were used, as $q_{100}$ can be estimated more robustly than trends and changes in the return period; the selection resulted in 3,738 stations (Extended Data Fig. 1a).

\section{Data availability}

The flood discharge data from the data holders/sources listed in Extended Data Table 1 that were used in this paper are available at https:/github.com/tuwhydro/ europe_floods. The precipitation and temperature data from the E-OBS dataset are available at www.ecad.eu/download/ensembles/ensembles.php. The CPC soil moisture data can be downloaded from www.esrl.noaa.gov/psd.

\section{Code availability}

The code used for the trend estimation and the extreme value analysis can be downloaded from https://github.com/tuwhydro/europe_floods.

31. Vogt, J. et al. A pan-European River and Catchment Database. Report No. EUR 22920 (Office for Official Publications of the European Communities, 2007).
32. Haylock, M. et al. A European daily high-resolution gridded data set of surface temperature and precipitation for 1950-2006. J. Geophys. Res. 113, D20119 (2008).

33. van den Dool, H., Huang, J. \& Fan, Y. Performance and analysis of the constructed analogue method applied to US soil moisture over 1981-2001. J. Geophys. Res. 108, 8617 (2003).

34. Sen, P. K. Estimates of the regression coefficient based on Kendall's tau. J. Am. Stat. Assoc. 63, 1379-1389 (1968).

35. Theil, H. A rank-invariant method of linear and polynomial regression analysis. Part 1. Proc. K. Ned. Akad. Wet. 53, 386-392 (1950).

36. Mann, H. B. Nonparametric tests against trend. Econometrica 13, 245-259 (1945).

37. Hiemstra, P. H., Pebesma, E. J., Twenhöfel, C. J. \& Heuvelink, G. B. Real-time automatic interpolation of ambient gamma dose rates from the Dutch radioactivity monitoring network. Comput. Geosci. 35, 1711-1721 (2009).

38. Wilcox, R. A note on the Theil-Sen regression estimator when the regressor is random and the error term is heteroscedastic. Biometrical J. 40, 261-268 (1998).

39. Helsel, D. R. \& Frans, L. M. Regional Kendall test for trend. Environ. Sci. Technol. 40, 4066-4073 (2006).

40. Renard, B., Lang, M. \& Bois, P. Statistical analysis of extreme events in a non-stationary context via a Bayesian framework: case study with peak-overthreshold data. Stoch. Env. Res. Risk A. 21, 97-112 (2006).

41. Martins, E. S. \& Stedinger, J. R. Generalized maximum-likelihood generalized extreme-value quantile estimators for hydrologic data. Wat. Resour. Res. 36, 737-744 (2000).

42. Watanabe, S. Asymptotic equivalence of Bayes cross validation and widely applicable information criterion in singular learning theory. J. Mach. Learn. Res. 11, 3571-3594 (2010).

Acknowledgements This work was supported by the ERC Advanced Grant 'FloodChange' project (number 291152), the Horizon 2020 ETN 'System Risk' project (number 676027), the DFG 'SPATE' project (FOR 2416), the FWF 'SPATE' project (I 3174) and a Russian Foundation for Basic Research (RFBR) project (number 17-05-41030 rgo_a). The data analysis was performed in $\mathrm{R}$ using the supporting packages automap, boot, lattice, maptools, ncdf4, plyr, raster, RColorBrewer, rgdal and rworldmap. The authors acknowledge the involvement in the data screening process of C. Álvaro Díaz, I. Borzì, E. Diamantini, K. Jeneiová, M. Kupfersberger, S. Mallucci and S. Persiano during their stays at the Vienna University of Technology. We thank L. Gaál and D. Rosbjerg for contacting Finnish and Danish data holders, respectively; B. Renard (France), W. Rigott (South Tyrol, Italy), G. Lindström (Sweden) and P. Burlando (Switzerland) for assistance in preparing and/or providing data or metadata from their respective regions. We acknowledge all flood data providers listed in Extended Data Table 1.

Author contributions G.B. and J. Hall designed the study and wrote the first draft of the paper. G.B. initiated the study. J. Hall collated the database with the help of most of the co-authors and conducted the analyses. A.V. conducted the MCMC analysis. G.B., J. Hall, A.V., R.A.P.P., J.P. and B.M. interpreted the results in the context of underlying geophysical mechanisms. J.P. compiled the catchment boundaries. D.L. contributed to the statistical analysis. M. Boháč, I.Č., A.K., S.K., O.L., M.M.-G., R.M., P.M., I.R., J.L.S., J.S. and N.Ž. interpreted the results in central Europe. G.T.A., A.B., O.B., M. Borga, A.C., G.B.C., P.C., D.G., A.M., L.M., M.Š., E.V. and K.Z. interpreted the results in southern Europe. B.A., J.J.K. and D.W. interpreted the results in northern Europe. J. Hannaford, S.H., T.R.K., N.M., C.M. and E.S. interpreted the results in western Europe. N.F., L.G., A.G., M.K., M.O. and V.O. interpreted the results in eastern Europe. All authors contributed to framing and revising the paper.

Competing interests The authors declare no competing interests.

\section{Additional information}

Supplementary information is available for this paper at https://doi. org/10.1038/s41586-019-1495-6.

Correspondence and requests for materials should be addressed to G.B. Reprints and permissions information is available at http://www.nature.com/ reprints. 


\section{RESEARCH LETTER}

a

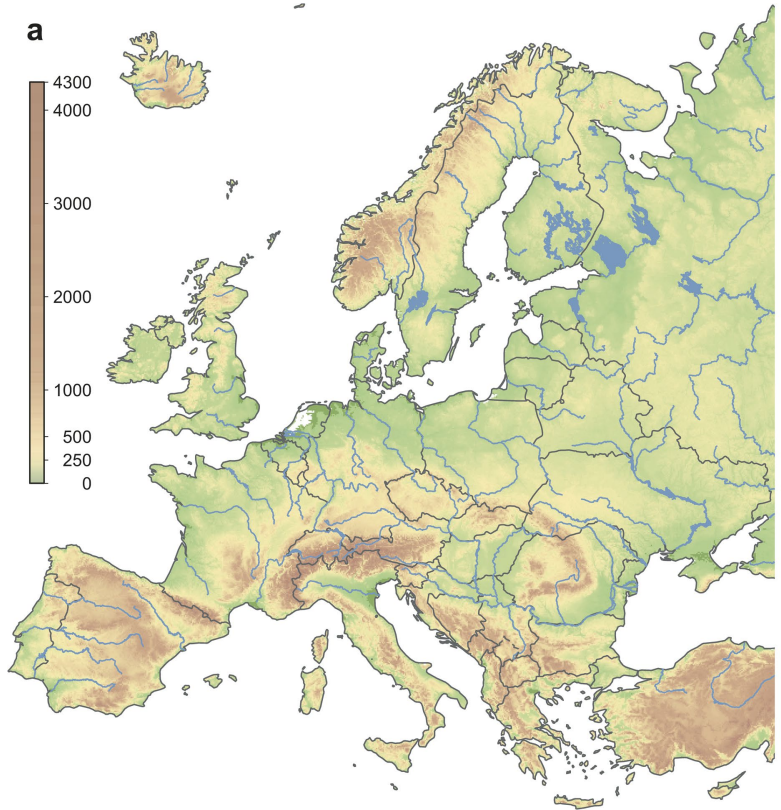

Extended Data Fig. 1 | Map of European study area. a, Elevation

(in metres above sea level), main rivers and lakes. b, Locations of the hydrometric stations analysed. Open and full circles indicate stations b

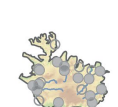

$-$

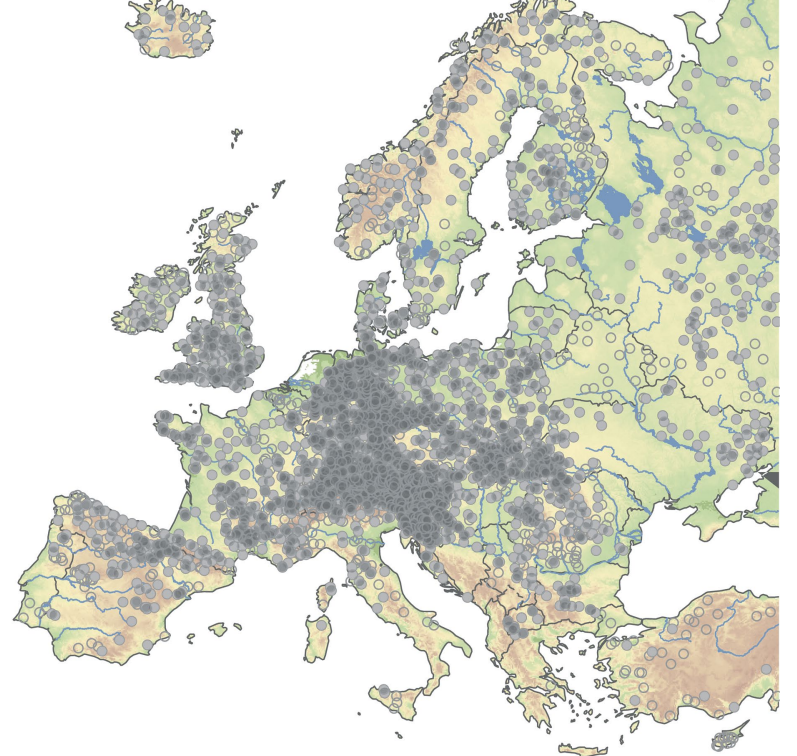

with more than 30 years $(n=3,738)$ and more than 40 years $(n=2,835)$ of flood discharge data, respectively. 


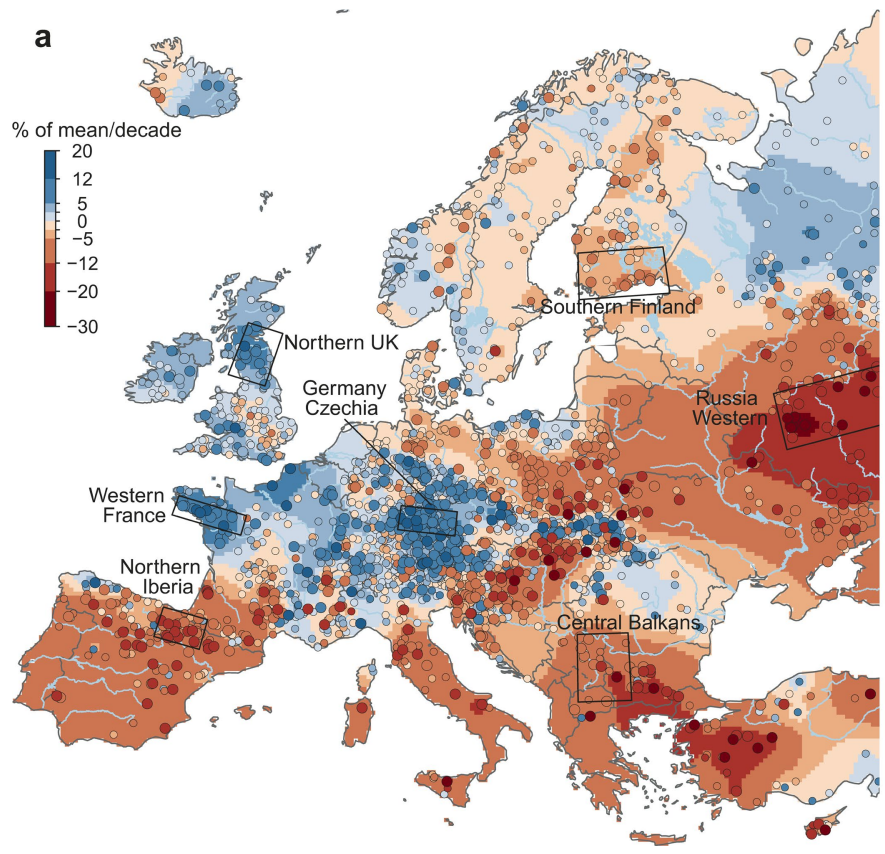

Extended Data Fig. 2 | Observed trends of river flood discharges in Europe (1960-2010). a, Points show local trends $(n=2,370)$, with larger points indicating statistically significant trends (significance level $\alpha=0.1$ ). Background pattern represents regional trends. Blue indicates increasing flood discharges and red denotes decreasing flood discharges. Rectangles

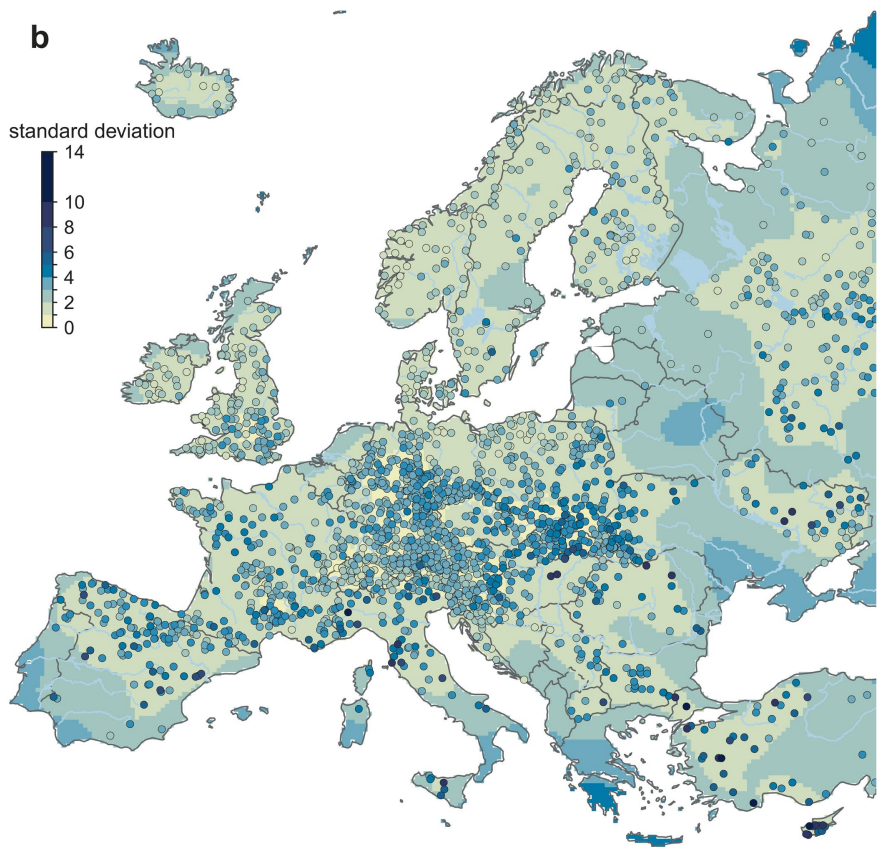

indicate hotspot areas as in Fig. 2, Extended Data Fig. 3, Extended Data Table 2c. b. Uncertainties of the trends in terms of standard deviation.

Points show local uncertainties. The background pattern represents regional uncertainties at the scale of a block size of $200 \times 200 \mathrm{~km}^{2}$. Units of both panels are per cent of mean per decade. 

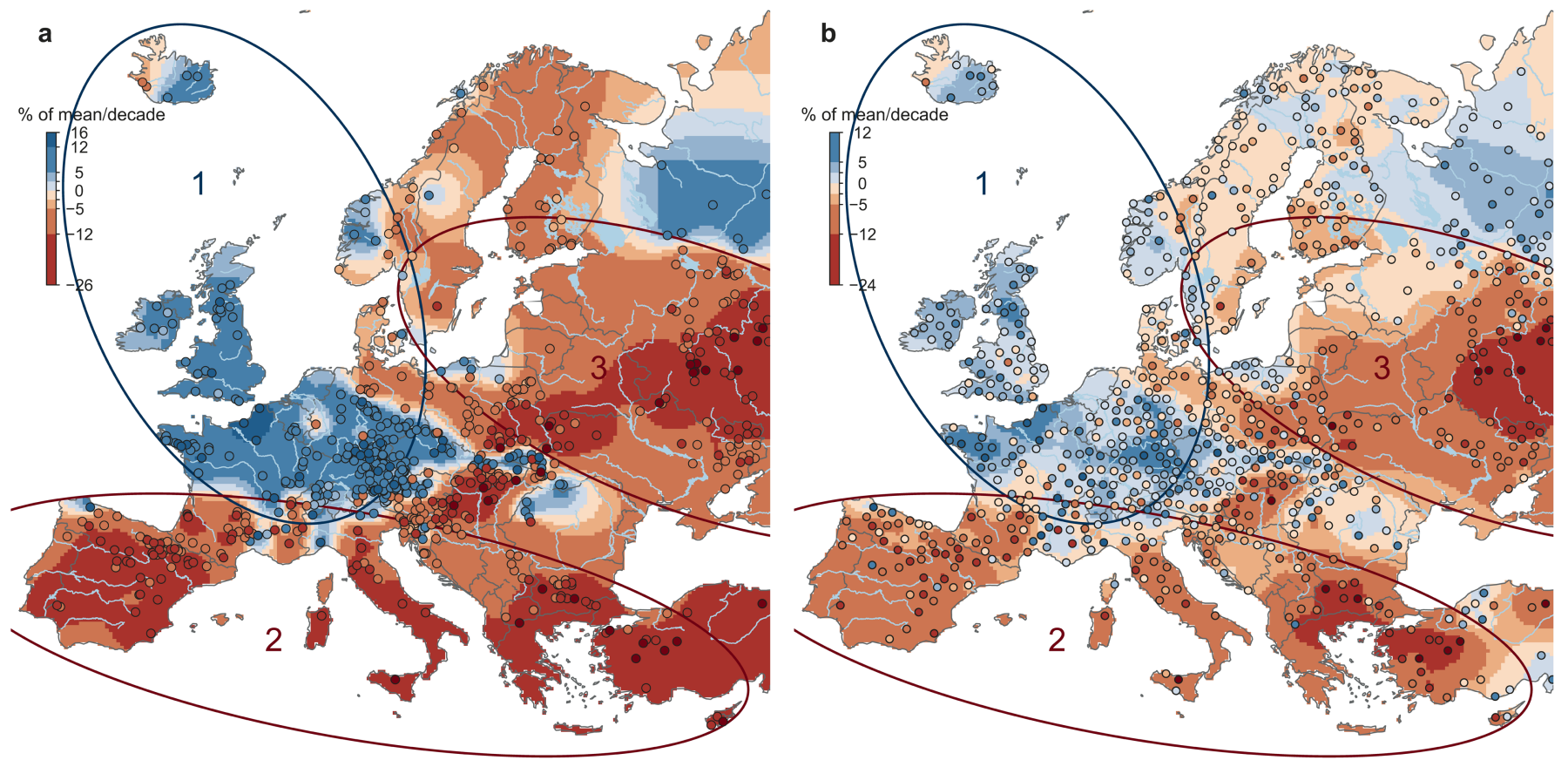

Extended Data Fig. 3 | Flood trends as in Fig. 1 and Extended Data Fig. 2, but using fewer stations. a, Only stations with significant trends are used $(n=664)$. b. Only stations with distances larger than $50 \mathrm{~km}$ from each other are used $(n=745)$. 

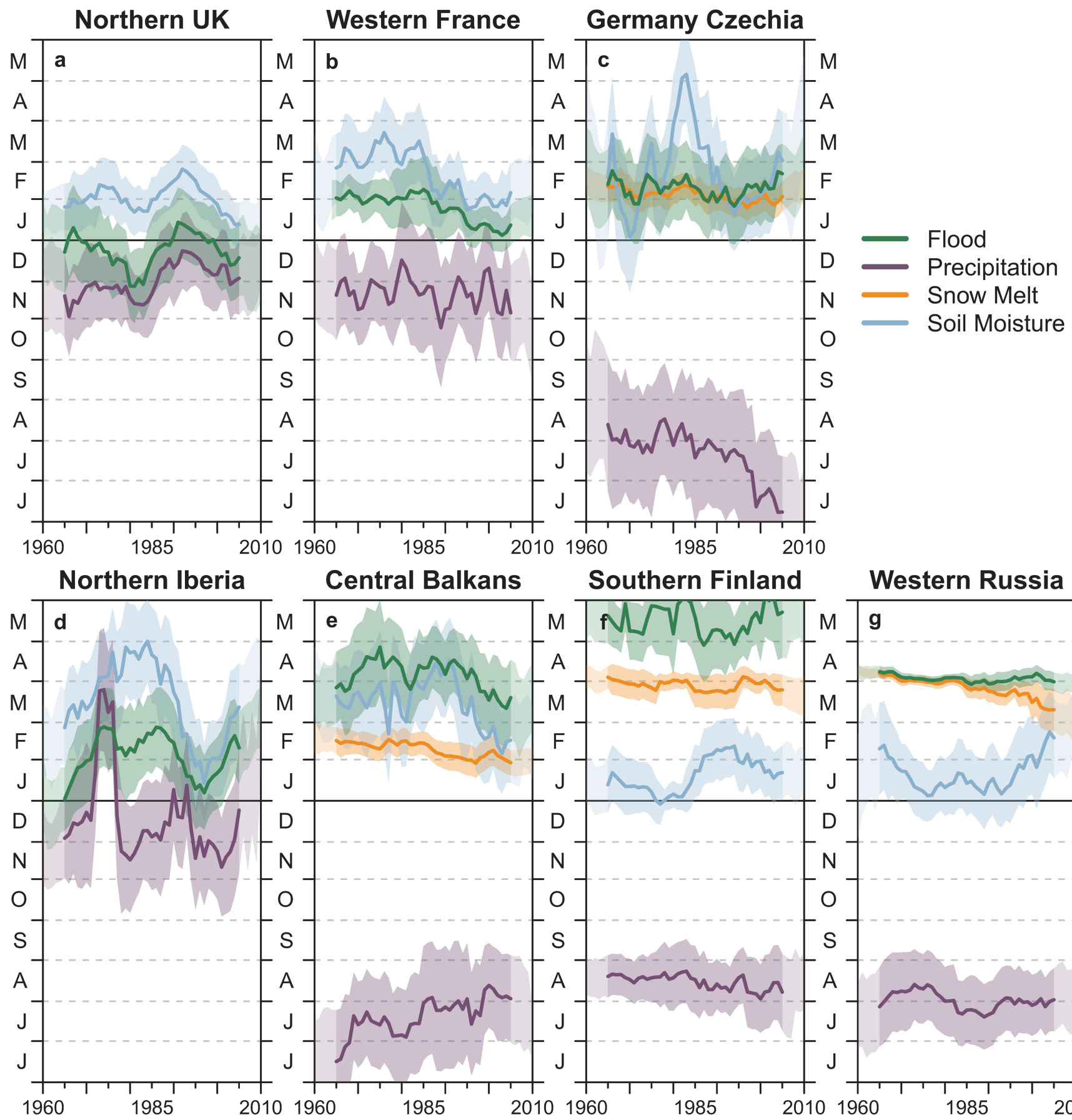

Western Russia

Extended Data Fig. 4 | Long-term temporal evolution of timing of floods and their drivers for seven hotspots in Europe. a, Northern United Kingdom; b, western France; c, southern Germany and western Czechia; d, northern Iberia; e, central Balkans; f, southern Finland; g, western Russia. Shown are the timing of observed floods (green), the seven-day maximum precipitation (purple), the snowmelt index (orange)

and the maximum monthly soil moisture (blue). Lines show the median timing and shaded bands indicate the variability of timing within the year ( \pm 0.5 circular standard deviations). All data were subjected to a circular ten-year moving-average filter. Vertical axes show month of the year (June to May). 


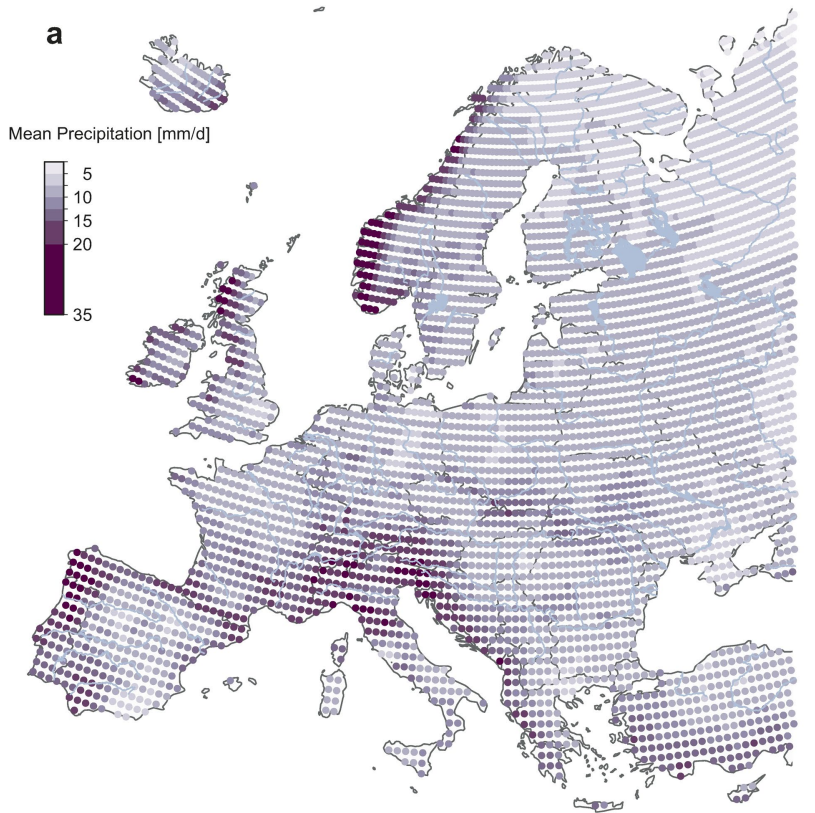

Extended Data Fig. 5 | Seven-day maximum precipitation (1960-2010). a, Long-term mean (in millimetres per day). b, Trends in precipitation (per cent of mean per decade), for which larger points indicate statistically

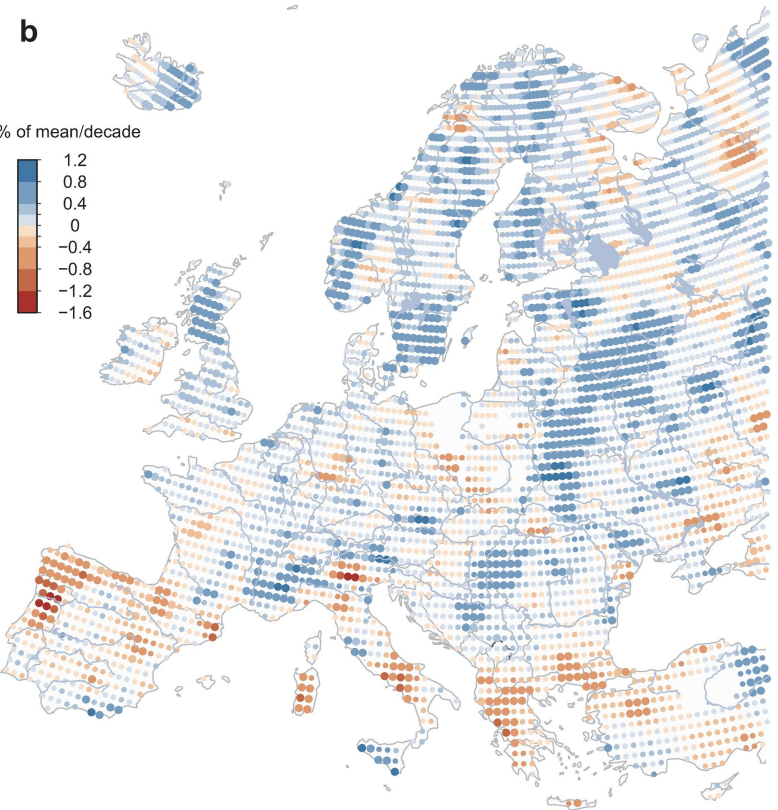

significant trends $(\alpha=0.1)$. Blue indicates increasing precipitation and red denotes decreasing precipitation. 
a

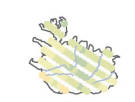

JFMA Temperature $\left[{ }^{\circ} \mathrm{C}\right]$

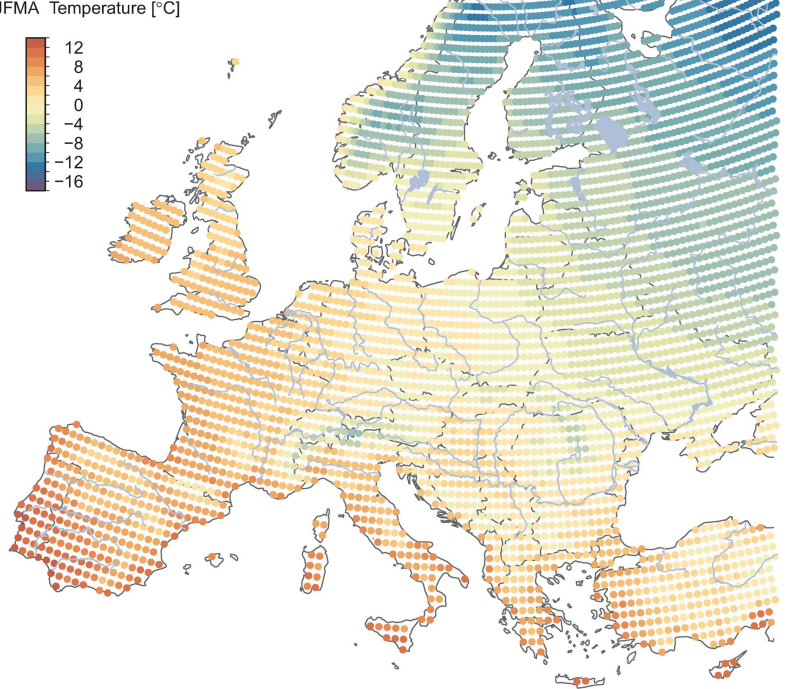

Extended Data Figure 6 | Spring (January to April) mean air

temperatures (1960-2010). a, Long-term mean (in degrees Celsius);

b, trends in temperatures (in degrees Celsius per decade), with larger b

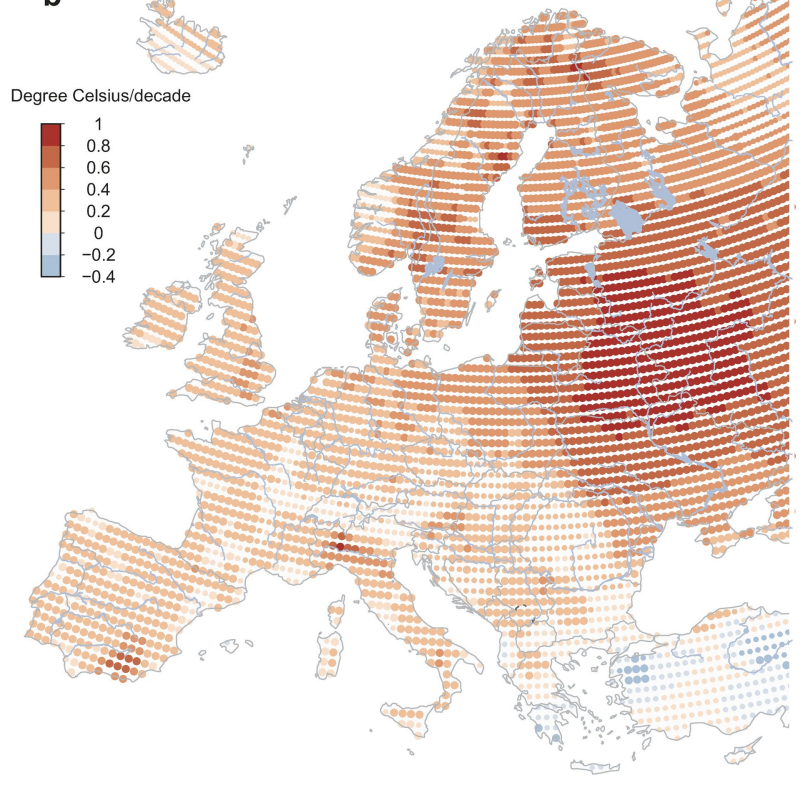

points indicating statistically significant trends $(\alpha=0.1)$. Red indicates increasing temperature and blue represents decreasing temperature. JFMA, January to April. 


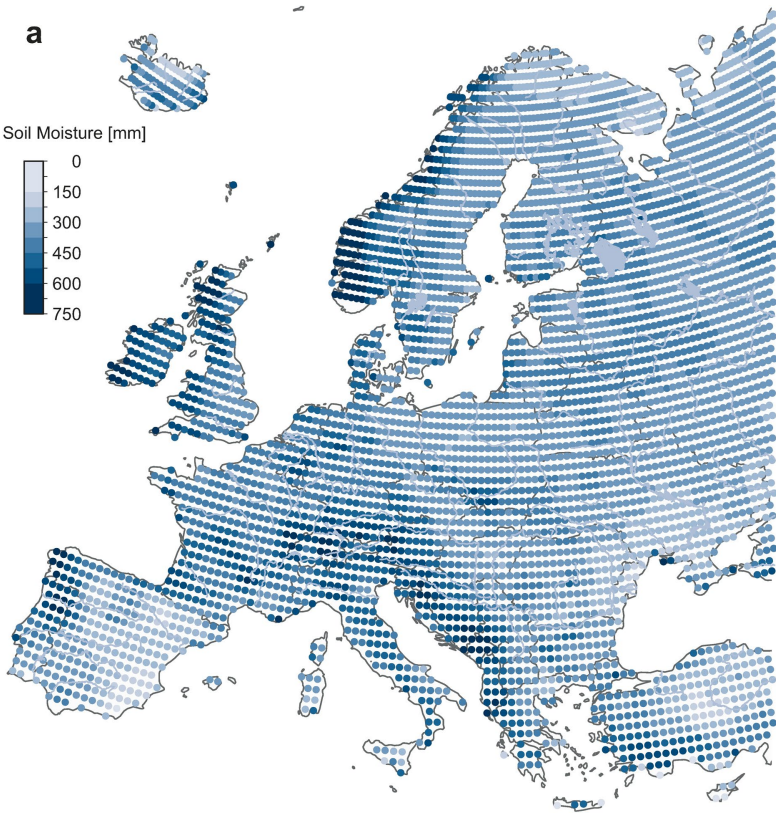

Extended Data Fig. 7 | Annual maximum monthly soil moisture

(1960-2010). a, Long-term mean (in millimetres). b, Trends in maximum soil moisture (per cent of mean per decade), for which larger points

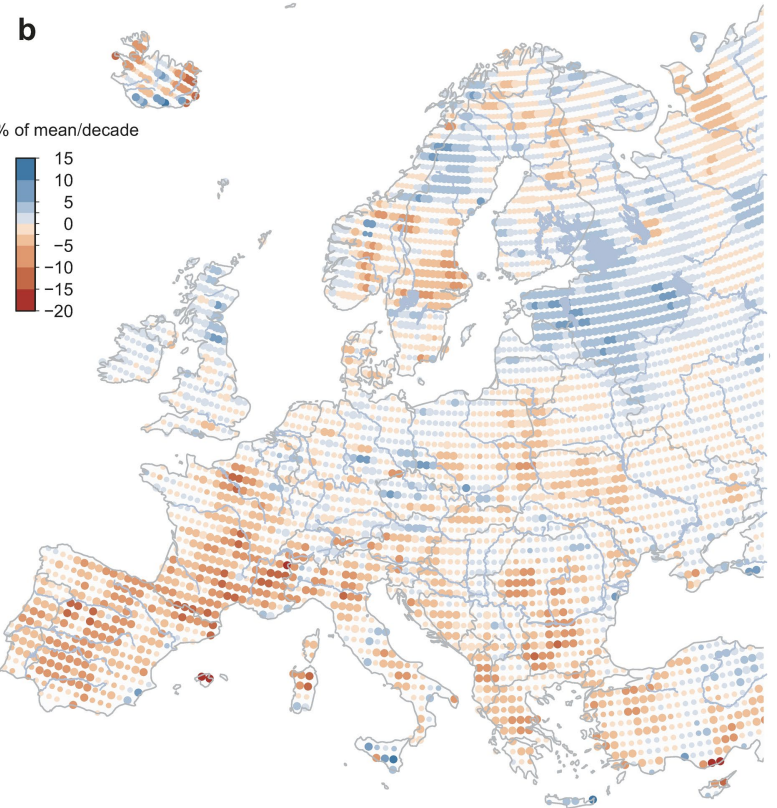

indicate statistically significant trends $(\alpha=0.1)$. Blue indicates increasing soil moisture and red denotes decreasing soil moisture. 


\section{$\mathrm{T}_{\mathrm{Q} 100}$}
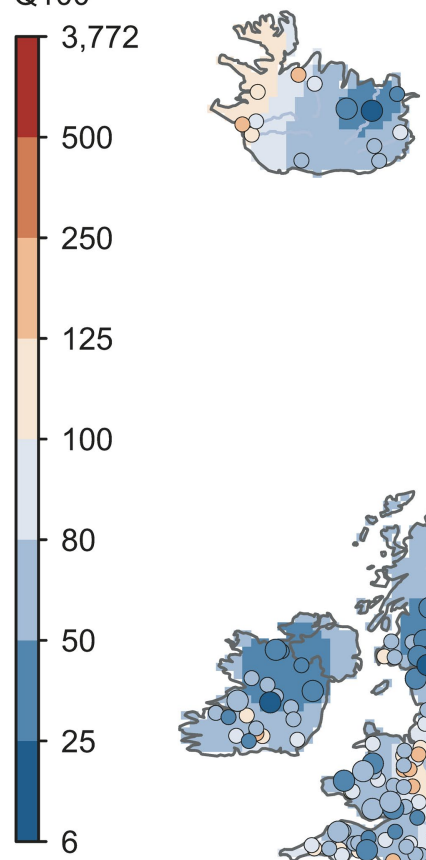

250

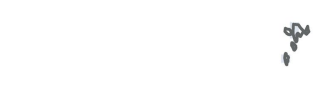

100

80
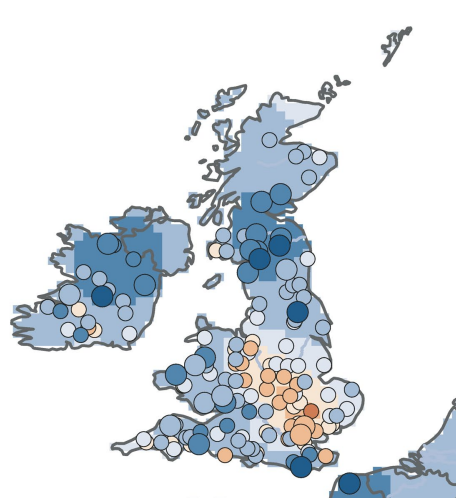

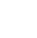

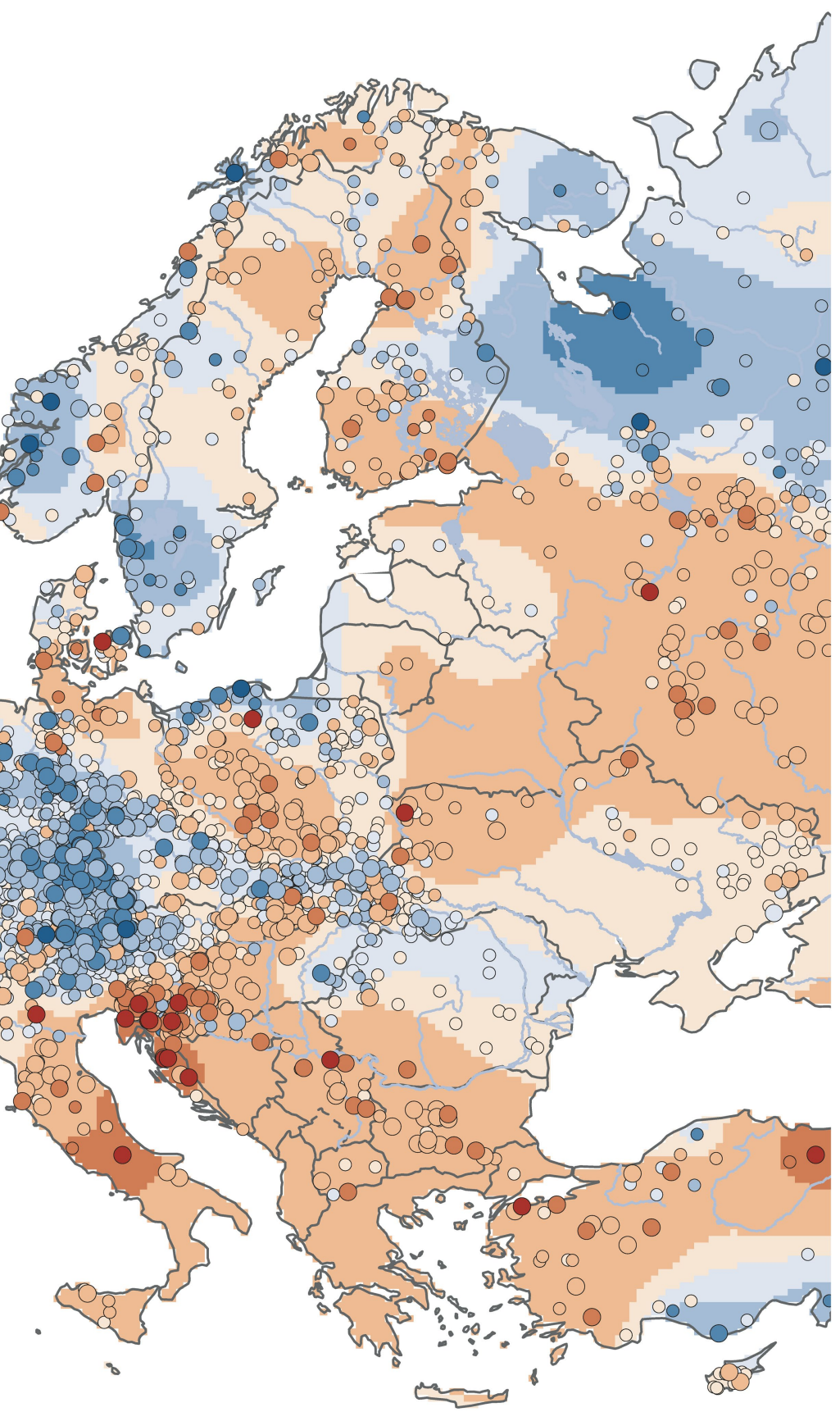

Extended Data Fig. 8 | Estimated return period in 2010 for the 1960

100-year flood discharge. Points show local return periods $(n=2,370)$, with larger points indicating agreement of the 5 th and the 95 th percentiles of the uncertainty distribution in the sign of change. The background pattern represents regional return periods. Blue indicates lower return periods, representing increasing flood discharges, and red indicates higher return periods, representing decreasing flood discharges. This figure provides a continental overview and does not replace national-scale and local studies, for which more detailed information may be available. 


\section{Extended Data Table 1 | Data sources included in the European Flood Database}

\begin{tabular}{|c|c|}
\hline Country/Project & Data Holder/Source/Project information \\
\hline Albania & National Hydro-Meteorological Service Albania, Institute of GeoSciences, Energy, Water and Environment (IGEWE) \\
\hline Austria & Hydrographic Services of Austria (HZB) \\
\hline Bosnia and Herzegovina & Hydrological Yearbooks of the former Republic of Yugoslavia \\
\hline Bulgaria & Hydrological Yearbooks of the Rivers in Bulgaria, National Institute of Meteorology and Hydrology \\
\hline Croatia & Meteorological and Hydrological Service of Croatia \\
\hline Czechia & Czech Hydrometeorological Institute \\
\hline Denmark & Danish Centre for Environment and Energy (DCE) \\
\hline Estonia & Estonian Environment Agency \\
\hline EWA & European Water Archive (EWA) \\
\hline Finland & Finnish Environment Institute, Open information/Hydrology/Discharge, Source: SYKE \\
\hline France & HYDRO database, French Ministry of Ecology, Sustainable Development and Energy \\
\hline Germany & Federal Waterways and Shipping Administration (WSV) \\
\hline Germany, Baden-Wuerttemberg & Ministry for the Environment, Climate and Energy of the Federal State of Baden-Wuerttemberg (LUBW) \\
\hline Germany, Bavaria & Flood Information Centre, Bavarian Environment Agency, Munich (LfU) \\
\hline Germany, Brandenburg & Ministry of Rural Development, Environment and Agriculture of the Federal State of Brandenburg (MLUL) \\
\hline Germany, Hessia & Hessian Agency for Nature Conservation, Environment and Geology (HLNUG) \\
\hline Germany, Lower Saxony & Lower Saxony Water Management, Coastal Defence and Nature Conservation Agency (NLWKN) \\
\hline Germany, Mecklenburg-W. Pomerania & State Office of Environment, Nature Protection and Geology of Mecklenburg-Western Pomerania (LUNG) \\
\hline Germany, North Rhine-Westphalia & State Agency for Nature, Environment and Consumer Protection (LANUV) \\
\hline Germany, Rhineland-Palatinate & State Office for the Environment, Water Management and Commerce Inspectorate Rhineland-Palatinate (LUWG) \\
\hline Germany, Saarland & The Saarland State Office for Environmental and Labour Protection (LUA) \\
\hline Germany, Saxony & Saxon State Agency for Environment, Agriculture and Geology (LfULG) \\
\hline Germany, Saxony-Anhalt & State Agency for Flood Defence and Water Management of Saxony-Anhalt (LHW) \\
\hline Germany, Schleswig-Holstein & Schleswig-Holstein Agency for Coastal Defence, National Park and Marine Conservation (LKN.SH) \\
\hline Germany, Thuringia & Thuringian Regional Office for the Environment and Geology (TLUG) \\
\hline GRDC & The Global Runoff Data Centre, Koblenz, Germany \\
\hline Greece & National Data Bank of Hydrological \& Meteorological Information (NDBHMI) \\
\hline Hungary & General Directorate of Water Management, Hungary \\
\hline $\begin{array}{l}\text { HYDRATE } \\
\text { Iceland }\end{array}$ & $\begin{array}{l}\text { EU-FP7 HYDRATE data: Hydrometeorological data resources and technology for effective flash flood forecasting } \\
\text { Icelandic Meteorological Office, Hydrological Database, No. 2013-10-27/01 }\end{array}$ \\
\hline Ireland & Irish Environmental Protection Agency (EPA) \\
\hline Ireland & Office of Public Works (OPW) \\
\hline Italy & CUBIST database, former SIMN (Servizio Idrografico e Mareografico Nazionale) \\
\hline Italy & National Research Council - Consiglio Nazionale delle Ricerche (CNR) \\
\hline Italy & ENEL (Ente Nazionale per l'Energia ELettrica) \\
\hline Italy & AdBPo (Autorità di Bacino del Fiume Po) \\
\hline Italy & IRPI (Istituto di Ricerca per la Protezione Idrogeologica) \\
\hline Italy & ISPRA (Istituto Superiore per la Protezione e la Ricerca Ambientale) \\
\hline Italy, Emilia-Romagna Region & ARPA (Agenzia Regionale per la Protezione dell' Ambiente) Emilia-Romagna \\
\hline Italy, Piedmont Region & ARPA Piemonte \\
\hline Italy, Lazio Region & Uffico Idrografico e Mareografico di Roma - Regione Lazio \\
\hline Italy, Sicily Region & Osservatorio delle Acque della Regione Siciliana \\
\hline Italy, South Tyrol Region & Hydrographic Office, Autonomous Province of Bolzano \\
\hline Italy, Trentino Region & Dipartimento Protezione Civile, Provincia Autonoma di Trento \\
\hline Italy, Umbria Region & Ufficio Idrografico - Regione Umbria \\
\hline Italy, Veneto Region & ARPA Veneto \\
\hline Latvia & Latvian Environment, Geology and Meteorology Centre, State Ltd. \\
\hline Lithuania & Lithuanian Hydrometeorological Service \\
\hline Macedonia & Macedonian Hydrometeorological Service \\
\hline Netherlands & Rijkswaterstaat - Dutch Ministry of Infrastructure and the Environment \\
\hline Norway & Norwegian Water Resources and Energy Directorate - Norges vassdrags- og energidirektorat (NVE) \\
\hline Poland & Institute of Meteorology and Water Management National Research Institute (IMGW-PIB) \\
\hline Portugal & Portuguese Environmental Agency, National Information System for Water Resources of Portugal (SNIRH) \\
\hline Romania & National Institute of Hydrology and Water Management - NIHWM \\
\hline Russia & $\begin{array}{l}\text { The main hydrological characteristics, } 1963-1970,1971-75,1975-1980,1980-2000 \\
\text { Ministry of Natural Resources and Ecology of the Russian Federation, State Hydrological Institute }\end{array}$ \\
\hline Russia & State Water Cadastre, 1985-2010, State Hydrological Institute, Lomonosov Moscow State University \\
\hline Russia & Automated information system of state water bodies monitoring (AIS GMVO), Federal Agency for Water Resources \\
\hline Serbia & Republic Hydrometeorological Service of Serbia (RHSS), Hydrological Yearbooks of Surface Water, Belgrade \\
\hline Slovakia & Slovak Hydrometeorological Institute (SHMI) \\
\hline Slovenia & Slovenian Environment Agency (ARSO) \\
\hline Spain & Centre for Hydrographic Studies (Centro de Estudios Hidrográficos) of CEDEX, Spain \\
\hline Sweden & Swedish Meteorological and Hydrological Institute (SMHI) \\
\hline Switzerland & Federal Office for the Environment (FOEN) / (BAFU) \\
\hline Turkey & General Directorate of Electrical Power Resources Survey and Development Administration (EIE), Turkey \\
\hline Ukraine & Hydrological Department, Ukrainian Hydrometeorological Institute (UHMI) \\
\hline Ukraine & Hydrometeorological Institute, Odessa State Environmental University (OSENU) \\
\hline United Kingdom & UK National River Flow Archive (NRFA) \\
\hline
\end{tabular}


Extended Data Table 2 | Flood trends in Europe

a)

\begin{tabular}{|c|c|c|c|c|}
\hline & & Positive Trend & Negative Trend & All \\
\hline \multirow{3}{*}{ Europe } & $\begin{array}{c}\text { Significant } \\
\alpha=0.1\end{array}$ & $273(11.52 \%)$ & $391(16.50 \%)$ & $664(28.02 \%)$ \\
\hline & $\begin{array}{c}\text { Not } \\
\text { Significant }\end{array}$ & $833(35.15 \%)$ & $837(35.31 \%)$ & $1706(71.98 \%)^{+}$ \\
\hline & All & 1106 (46.67\%) & $1228(51.81 \%)$ & $2370^{+}$ \\
\hline \multirow{3}{*}{$\begin{array}{l}\text { Region 1: } \\
\text { North- } \\
\text { western } \\
\text { Europe }\end{array}$} & $\begin{array}{c}\text { Significant } \\
\alpha=0.1\end{array}$ & $182(20.34 \%)$ & 27 (3.01\%) & $209(23.35 \%)$ \\
\hline & $\begin{array}{c}\text { Not } \\
\text { Significant }\end{array}$ & 435 (48.60\%) & $240(26.82 \%)$ & $686(76.65 \%)^{+}$ \\
\hline & All & $617(68.94 \%)$ & $267(29.83 \%)$ & $895^{+}$ \\
\hline \multirow{3}{*}{$\begin{array}{l}\text { Region 2: } \\
\text { Southern } \\
\text { Europe }\end{array}$} & $\begin{array}{c}\text { Significant } \\
\alpha=0.1\end{array}$ & $13(2.84 \%)$ & $142(31.00 \%)$ & $155(33.84 \%)$ \\
\hline & $\begin{array}{c}\text { Not } \\
\text { Significant }\end{array}$ & 96 (20.96\%) & $169(42.80 \%)$ & $303(66.16 \%)^{+}$ \\
\hline & All & $109(23.80 \%)$ & $338(73.80 \%)$ & $458^{+}$ \\
\hline \multirow{3}{*}{$\begin{array}{l}\text { Region 3: } \\
\text { Eastern } \\
\text { Europe }\end{array}$} & $\begin{array}{c}\text { Significant } \\
\alpha=0.1\end{array}$ & $5(1.77 \%)$ & $115(40.78 \%)$ & $120(42.55 \%)$ \\
\hline & $\begin{array}{c}\text { Not } \\
\text { Significant }\end{array}$ & $54(19.15 \%)$ & $104(36.88 \%)$ & $162(57.45 \%)^{+}$ \\
\hline & All & $59(20.92 \%)$ & $219(77.66 \%)$ & $282^{+}$ \\
\hline
\end{tabular}

b)

\begin{tabular}{|c|c|c|c|c|c|c|c|}
\hline & Northern UK & $\begin{array}{c}\text { Western } \\
\text { France }\end{array}$ & $\begin{array}{l}\text { Germany } \\
\text { Czechia }\end{array}$ & $\begin{array}{l}\text { Northern } \\
\text { Iberia }\end{array}$ & $\begin{array}{l}\text { Central } \\
\text { Balkans }\end{array}$ & $\begin{array}{l}\text { Southern } \\
\text { Finland }\end{array}$ & $\begin{array}{l}\text { Western } \\
\text { Russia }\end{array}$ \\
\hline Precipitation & 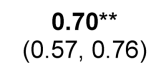 & $\begin{array}{c}0.41^{*} \\
(0.15,0.64)\end{array}$ & $\begin{array}{c}0.40^{*} \\
(0.24,0.56)\end{array}$ & $\begin{array}{c}\mathbf{0 . 5 4}^{\star *} \\
(0.39,0.68)\end{array}$ & $\begin{array}{c}0.22 \\
(-0.11,0.49)\end{array}$ & $\begin{array}{c}0.08 \\
(-0.11,0.28)\end{array}$ & $\begin{array}{c}-0.13 \\
(-0.4,0.18)\end{array}$ \\
\hline Soil Moisture & $\begin{array}{c}0.36^{*} \\
(-0.01,0.66)\end{array}$ & $\begin{array}{c}\mathbf{0 . 5 7}^{* *} \\
(0.39,0.71)\end{array}$ & 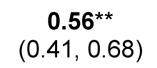 & $\begin{array}{c}0.37^{*} \\
(0.12,0.55)\end{array}$ & $\begin{array}{c}\mathbf{0 . 6 8} \mathbf{8}^{\star *} \\
(0.50,0.76)\end{array}$ & $\begin{array}{c}0.20 \\
(0.01,0.4)\end{array}$ & $\begin{array}{c}0.30 \\
(0.07,0.49)\end{array}$ \\
\hline Spring temperature & $\begin{array}{c}0.09 \\
(-0.15,0.25)\end{array}$ & $\begin{array}{c}0.5^{* *} \\
(0.33,0.63)\end{array}$ & $\begin{array}{c}0.04 \\
(-0.19,0.23)\end{array}$ & $\begin{array}{c}0.02 \\
(-0.23,0.32)\end{array}$ & $\begin{array}{c}-0.29 \\
(-0.44,-0.12)\end{array}$ & $\begin{array}{c}-\mathbf{0 . 3 4} \\
(-0.49,-0.15)\end{array}$ & $\begin{array}{c}-\mathbf{0 . 5 5} 5^{\star \star} \\
(-0.7,-0.3)\end{array}$ \\
\hline
\end{tabular}

c)

\begin{tabular}{crrrrr}
\hline $\begin{array}{c}\text { Hotspot } \\
\text { Name }\end{array}$ & $\begin{array}{c}\text { No. of } \\
\text { Stations }\end{array}$ & $\begin{array}{c}\text { Minimum } \\
\text { trend }\end{array}$ & $\begin{array}{c}\text { Maximum } \\
\text { trend }\end{array}$ & $\begin{array}{c}\text { Mean } \\
\text { hotspot } \\
\text { trend }\end{array}$ & $\begin{array}{c}\text { Signifi- } \\
\text { cance }\end{array}$ \\
\hline $\begin{array}{c}\text { Northern } \\
\text { UK }\end{array}$ & 15 & 2.9 & 12.5 & 6.6 & $\alpha<0.01$ \\
$\begin{array}{c}\text { Western } \\
\text { France }\end{array}$ & 16 & 5.9 & 17.6 & 9.7 & $\alpha<0.01$ \\
$\begin{array}{c}\text { Germany } \\
\text { Czechia }\end{array}$ & 47 & 1.6 & 17.8 & 8.0 & $\alpha<0.01$ \\
$\begin{array}{c}\text { Northern } \\
\text { Iberia }\end{array}$ & 34 & -18.3 & 3.8 & -8.3 & $\alpha<0.01$ \\
$\begin{array}{c}\text { Central } \\
\text { Balkans }\end{array}$ & 15 & -17.6 & -0.1 & -8.4 & $\alpha<0.01$ \\
$\begin{array}{c}\text { Southern } \\
\text { Finland }\end{array}$ & 15 & -10.0 & -2.1 & -5.2 & $\alpha<0.01$ \\
$\begin{array}{c}\text { Western } \\
\text { Russia }\end{array}$ & 21 & -28.8 & -8.3 & -18.2 & $\alpha<0.01$ \\
\hline
\end{tabular}

a, Number of stations with positive and negative flood discharge trends. The numbers in parentheses are the percentages of stations relative to the total number of stations in Europe or in a region. Regions as in Fig. 1. b. Estimates and $90 \%$ confidence bounds (in parentheses) of Spearman's rank correlation coefficient between hotspot medians of the annual series of flood discharge and their drivers. c, Flood discharge trends for selected hotspots (in per cent of station mean per decade). The significance level of the general hotspot trends is given according to the regional Mann-Kendall test ${ }^{39}$ with significance level $\alpha$.

+ Stations with no trends are included.

$* P<0.01 ; * * P<0.001$ 